\title{
How do Electoral Systems Affect Fiscal Policy? Evidence from State and Local Governments, 1890 to 2005
}

\author{
Patricia Funk \\ Christina Gathmann
}

CESIFO WORKING PAPER NO. 2958

CATEgory 1: Public FinANCE

FEBRUARY 2010
An electronic version of the paper may be downloaded
- from the SSRN website:
www.SSRN.com
- from the RePEc website:
www.RePEc.org
- from the CESifo website:
www.CESifo-group.org/wp




\title{
How do Electoral Systems Affect Fiscal Policy? Evidence from State and Local Governments, 1890 to 2005
}

\begin{abstract}
Using a new data set on Swiss state and local governments from 1890 to today, we analyze how the adoption of proportional representation affects fiscal policy. We show that proportional systems shift spending toward broad goods (e.g. education and welfare benefits) but decrease spending on targetable goods (e.g. roads and agricultural subsidies). Our evidence does not suggest that proportional representation increases the overall size of government. We provide new evidence on the mechanism behind these estimates. We show that proportional elections lead to better political representation of left-wing parties, which are associated with more spending. Furthermore, proportional elections lead to higher political fragmentation. However, since political fragmentation increases spending in a plurality system only, proportional elections reduce spending through its more moderate effects of fractionalized parliaments.
\end{abstract}

JEL-Code: H00, H10, H40, H52, H53, H72, N83, N84.

Keywords: electoral system, public finance, political fragmentation, matching.

Patricia Funk

Department of Economics

University Pompeu Fabra

Patricia.Funk@upf.edu
Christina Gathmann

University of Mannheim

cgathmann@uni-mannheim.de

This Draft: January 2010

We thank Toke Aidt, Tim Besley, Ann Carlos, Latika Chaudhary, Axel Dreher, Lars Feld, Bob Hall, Eckhard Janeba, Peter Lindert, John Matsusaka, Jan Schnellenbach, Erik Snowberg, Guido Tabellini, Susan Wolcott and seminar participants at the AEA meeting, World Congress of the Cliometrics Society, Hoover Institution, EEA Meeting, Silvaplana Workshop of Political Economy, University of Alicante, Bonn, Heidelberg, Mannheim, Zurich, EconomiX - Paris and Universitat de Barcelona for many helpful comments. We are very grateful to the employees of canton archives for answering our questions and to Andreas Ladner and Georg Lutz for sharing their data. 


\section{Introduction}

A central feature of representative democracies is the delegation of decision-making power to political representatives by the electorate. Electoral systems play hereby a crucial role because they shape electoral incentives and the legislative environment in which public policies are made. Theories of electoral systems show that a plurality system encourages politicians to represent the interests of their local district, while politicians in a proportional system typically seek support among broad social groups (Austen-Smith, 2000; Lizzeri and Persico, 2001; Milesi-Ferretti et al., 2002; Myerson, 1993; Persson and Tabellini, 2003). A central prediction emerging from these models is that plurality systems favor spending on goods that can be targeted locally, while the proportional system fosters spending on goods with benefits that are not specific to a local clientele. How these different incentives affect overall government spending is theoretically much less clear.

To analyze the effects of electoral systems on fiscal policy however, faces a number of empirical challenges: for one thing, constitutional reforms are relatively rare. In addition, sharp differences between electoral systems are typically only observed across countries, not within a single country. The combination of cross-sectional variation in electoral systems across different countries makes the identification of fiscal effects difficult.

The methodological innovation of this article is that we exploit unique variation in electoral systems at the state and local level in Switzerland to estimate the effect of proportional representation on fiscal policy. Our setting has a number of attractive features. Switzerland's federalist system created considerable variation in electoral rules at the sub-national level. Some states ('cantons') use a proportional, others a plurality system to elect their parliament. Hence, we can use institutional variation at the sub-national level to carefully analyze the link between electoral system and economic policies. Since all cantons share a common history, our approach reduces problems of unquantifiable historical and institutional differences inherent in cross-country studies. Further, we can use rare exogenous variation in electoral rules for local governments to better address the problem of policy endogeneity (Acemoglu, 
2005; Aghion et al., 2004). For local elections, many cantons in Switzerland mandate proportional or plurality rule. Since these mandates have been imposed several decades ago, they are plausibly uncorrelated with current local finances, local political factions or other social conditions in a community.

Finally, our analysis investigates a historical milestone of constitutional reform in Western Europe, the switch from plurality rule to proportional representation. In 1890, all cantons, like all democratic countries around in the world, elected their state legislatures under a plurality system. Over the next 110 years, 23 of the 25 cantons in Switzerland have switched to proportional representation. Today, only two cantons exclusively rely on plurality rule to elect their parliament. Hence, our setting provides a unique opportunity to identify the influence of proportional representation from geographical and temporal variation within the boundaries of a single country. Though pioneering, Swiss cantons were by no means the only political units that have adopted the new electoral system. On the contrary, many states in Europe and elsewhere switched to proportional representation after 1890. The first country to adopt it at the national level was Belgium in 1899; Germany followed in 1918, Ireland in 1919 and France in 1945. We therefore believe that our analysis is valid beyond the particular Swiss setting.

The second, substantive contribution of this article is that we uncover new evidence on the theoretical mechanism of the reduced-form estimates. Electoral systems not only yield distinct electoral incentives. They also differ in the organization of the legislature they create. Proportional systems often result in politically fragmented legislatures and coalition governments. As demonstrated by Weingast et al. (1981) and others (e.g. Poterba and von Hagen, 1999), political fragmentation creates a 'commonpool problem' when projects benefit a particular group but are financed by the entire jurisdiction. Because legislators value the full benefits of spending projects for their constituency, but internalize only a part of their costs, logrolling among politicians will result in more government spending. Recent models however argue that proportional representation might actually produce more homogenous party platforms (Lizzeri and Persico, 2009) and fewer relevant decision-makers because of party discipline (Carey and Shugart, 1995). Both should reduce the common-pool problem associated with political 
fragmentation. Our empirical analysis separates the effects of changes in political fragmentation from that of political representation and electoral incentives. In particular, we test for the first time whether political fragmentation, though higher under proportional representation, creates less of a common-pool problem than in a plurality system.

Our main findings can be summarized as follows. Proportional representation has strong effects on the composition of government: it shifts spending away from geographically targeted transfers to roads and agricultural subsidies toward spending on education and welfare that benefit broad social groups. Specifically, we find that a proportional system raises education expenditures by 12 percent, welfare expenditures by 30 percent, but also decreases road expenditures by 50 percent and agricultural subsidies by 21 percent.

We find little evidence that proportional representation results in larger government spending or revenues. The absence of an effect on overall spending is driven by offsetting forces. On the one hand, the stronger political representation of left-wing interests in proportional systems increases spending by 6.6 percent. On the other hand, we find evidence that political fragmentation leads to less overspending in a proportional system. While common-pool problem arising from political fragmentation increases spending in a plurality system (32 percent), this effect is essentially absent in a proportional system. This finding is consistent with greater party discipline or stronger convergence of party platforms, which reduces the relevant number of political interests in a proportional system. Consistent with our reduced-form estimates, we find that the net effect of these changes on total spending is zero.

An important concern with our empirical strategy is that unobservable factors may be correlated with spending and the decision to adopt a proportional system. We conduct a number of validity tests at the canton and local level which demonstrate that the link between electoral reform and public spending is indeed causal. First, we compare local spending in communities that have exogenously imposed proportional representation to spending in communities with imposed plurality rule. We find no evidence that spending is higher in communities with mandated proportional rule. Across all specifications, 
our analysis of communities strongly supports the findings at the canton level. Second, we present a number of dynamic panel estimators to account for serial correlation and potential nonstationarity in our spending variables. Our results remain unchanged and remain statistically significant even after standard errors are adjusted for serial correlation (Bertrand et al., 2004).

Third, we show that the relationship between proportional system and public spending is robust to controls for other political and social reforms during that period, such as direct democratic participation rights, the adoption of direct elections for the executive and women's suffrage. Further, allowing for canton-specific linear trends or canton-specific decade dummies to capture unobservable trend differences between cantons or the effect of canton-specific shocks does not change our qualitative results. Fourth, we find few meaningful relationships between the adoption of proportional representation and the timing of other political and institutional reforms. Fifth, we show that attempts to reform the electoral system that did not ultimately lead to proportional representation have little effect on public spending. Taken together, the results for canton and local governments suggest that it was the adoption of proportional representation itself that shifted the scope of government but did not increase its overall size.

The remainder of the paper is structured as follows. Section 2 relates our work to the most relevant strands of literature. Section 3 describes the historical background surrounding the adoption of proportional elections. The data and empirical strategy is presented in section 4 . We present our canton-level results in section 5 and corroborate our findings at the local level in section 6 . Section 7 concludes.

\section{Related literature}

The two prominent electoral systems used in democracies today, plurality and proportional system, can be broadly characterized as follows: candidates in a plurality system are elected in a large number of voting districts (e.g. single-member districts). The seat is then awarded to the candidate with the highest share of votes in that district (winner-takes-all or first-past-the-post system). In a proportional system in turn, seats in the legislature are distributed in a small number of (or even a single) voting 
districts and are assigned based on the share of votes for the candidate's party. ${ }^{1}$ We now discuss how these differences affect electoral incentives and the organization of the legislature.

\subsection{Electoral Incentives and Legislative Organization}

Theories of the electoral system typically assume two-party competition in which candidates choose two different policies: one with benefits for many voters ('broad good'), and a second one, which can be targeted to subsets of voters ('targetable good'). A central prediction emerging from these models is that candidates elected in a plurality system will spend more on the targetable good and less on the good with diffuse benefits than candidates elected in a proportional system (Lizzeri and Persico, 2001;

Milesi-Ferretti et al., 2002; Persson and Tabellini, 2003).

This prediction holds irrespective of whether the electoral system is defined by the electoral rule (Lizzeri and Persico, 2001), or the numbers of districts (Milesi-Ferretti et al., 2002; Persson and Tabellini, 2003), in which representatives are elected. Candidates facing plurality rule have stronger incentives to target spending on voters that secure their majority, while votes above the majority are discarded. Under proportional rule in contrast, every vote counts. A similar conclusion emerges when electoral systems are distinguished by their district size. Candidates elected under plurality system are elected in many small districts. To win the majority, candidates want to spend more in highly contested districts. In both cases, a plurality system encourages spending on goods that are targetable to pivotal voters relative to goods with diffuse benefits.

How electoral incentives affect total spending under the two systems is less clear. First, total spending might be higher or lower in proportional systems depending on voter preferences over targetable spending relative to broad transfers (Milesi-Ferretti et al., 2002). If the median voter values targetable goods, total spending will be higher in a proportional system. ${ }^{2}$ The effect on total spending also depends on

\footnotetext{
${ }^{1}$ Electoral systems may also vary along other, more subtle dimensions. See Taagepera and Shugart (1989), Lijphart (1994) and Cox (1997) for a thorough discussion of real-world electoral systems.

${ }^{2}$ The reason is that proportional representation also encourages spending on broad transfers. The sum of spending on goods with broad and those with targetable transfers in the proportional system will then exceed spending in a plurality system which is concentrated on targetable goods.
} 
the relative strength of electoral competition. Plurality systems might impose barriers to entry because the chances of success for alternative candidates from the same party are low in single-member districts (Myerson, 1993). ${ }^{3}$ As a consequence, the effect of proportional representation on the overall size of government is theoretically ambiguous.

The existing models assume two-party competition, and hence take the organization of the legislature as given. ${ }^{4}$ However, a large literature in political science has documented that proportional systems increase the number of parties and political fragmentation in the legislature (Duverger, 1954; Rae, 1967; Lijphart, 1990; Persson et al., 2007; Taagepera and Shugart, 1989). Weingast, Shepsle and Johnson (1981) provide an early formalization of the consequences of political fragmentation in a plurality system. In their model, representatives are elected in their specific district, but spending decisions are financed by general taxation. Candidates then have an incentive to target spending toward their support base. Since the costs are borne by all taxpayers, this gives rise to a 'common-pool problem': each candidate favors more spending on projects that benefit their voters, while they consider only a fraction of the overall cost. ${ }^{5}$ Their model predicts that spending increases as the pool of decision-makers over the budget gets larger (Austen-Smith, 2000; Bawn and Rosenbluth, 2006; Poterba and von Hagen, 1999).

Does this prediction also apply to the proportional system where candidates are elected in large or nationwide districts? There are at least two reasons why the effect of political fragmentation might be weaker in a proportional system. One argument is that the electoral system has an effect on the policy platforms chosen by parties. As shown by Lizzeri and Persico (2009), policy platforms are typically less risky (hence, closer to each other) in a proportional than in plurality system. The effect

\footnotetext{
${ }^{3}$ In addition, electoral competition, which reduces wasteful spending, might be more or less intense in a plurality system. On the one hand, competition among candidates is stronger in the highly contested districts because the return of winning is high in a plurality system (Persson and Tabellini, 2003). On the other hand, electoral competition is lower in 'safe' districts.

${ }^{4}$ Standard spatial models in contrast, do not yield sharp predictions. In a model with two parties and linear taxes, we obtain the full convergence of policies. With three parties, two parties are symmetrically located around the median in equilibrium, while the third party with the fewest votes is located at the median. Policies are chosen by a coalition between the small party and one of the large parties. Actual policies might then be above or below the desired policy of the median voter (e.g. Austen-Smith and Banks, 1988).

${ }^{5} \mathrm{~A}$ large public finance literature has stressed the importance of common-pool problems for delaying fiscal adjustment (see for example, Alesina and Perotti, 1995; Poterba und von Hagen, 1999).
} 
on party platforms suggests that political differences between parties might actually be smaller in a proportional system (see Ezrow, 2009 for cross-country evidence consistent with this hypothesis). While the number of decision-makers is certainly higher under proportional representation, actual divergence of positions might be lower, which would dampen the overspending bias inherent in common-pool models. A second reason political fragmentation might have less damaging effects in a proportional system is party discipline. If party leaders have control over the nomination of political candidates, policy positions among candidates of the same party might be more homogenous, and party discipline in parliamentary decisions more pronounced (see Carey and Shugart, 1995 for the theoretical argument and Norris, 2004 for empirical evidence). Hence, while the sheer number of bargaining partners is larger in a proportional system, the true number of decision-makers might be lower and hence less prone to overspending.

Finally, parties in a proportional system could target voters that would not be pivotal in a twoparty system (Lizzeri and Persico, 2005). ${ }^{6}$ The adoption of proportional representation would then also affect the set of interests represented in parliament. During our study period, the workers' movement gained political influence which increased left-wing representation in the parliaments after the adoption of proportional representation. To the extent that left-wing supporters prefer more government, this change in representation results in more spending.

In sum, our discussion yields the following empirical tests: first, governments in a proportional system provide more spending with diffuse benefits to society but spend less on targetable goods. Second, the effect on the size of government is theoretically ambiguous. Third, a politically fragmented legislature spends more if elected in a plurality system. The effect of political fragmentation on spending might be less pronounced in a proportional system. Finally, spending increases in the parliamentary strength of groups with a more demand for government.

\footnotetext{
${ }^{6}$ Alternatively, voters in a proportional system might actually strategically elect candidates with a preference for social transfers rather than candidates with a taste for locally targetable goods (Milesi-Ferretti et al., 2002).
} 


\subsection{Empirical Studies}

The existing empirical literature on proportional representation is based on cross-country data (Aidt et al., 2006; Milesi-Ferretti et al., 2002; Persson and Tabellini, 2003). Their analyses reveal that welfare spending is correlated with having a proportional system. The correlations for the overall size of government are less conclusive and seem to depend on the specific country sample.

This study makes two important contributions to this literature. Our methodological contribution is that we rely on variation in constitutional rules at the sub-national level which reduces concerns of omitted variables. Specifically, we draw on Swiss data on state and local governments to investigate the effects of proportional representation within the boundaries of a single country. ${ }^{7}$ An analysis at the subnational level is especially attractive because electoral systems typically vary along many dimensions across countries, which are difficult to characterize with existing data. In contrast to earlier studies, our identification is based on the differential timing of constitutional reform across individual cantons. Hence, we can control for fixed differences across cantons and unobservable canton-specific trends or shocks to identify the effects of proportional representation on fiscal policies. Further, we can employ plausibly exogenous variation at the local level to bolster our confidence in interpreting the canton estimates as causal.

Our second substantive contribution to the literature is to shed light on the theoretical mechanism driving the reduced-form estimates. While the theory of electoral systems is by now well developed, we know little about the precise mechanism behind the empirical correlations. Our setting allows us to shed light on how electoral incentives and changes in the organization of the legislature affect policy choices and quantify for the first time their relative importance for fiscal policy.

In addition, our article also contributes to the literature on political fragmentation and fiscal policy (Alesina and Perotti, 1995; Baqir, 2002; Bradbury and Crain, 2001; Chen and Maholtra, 2007; Gilligan and Matsusaka, 2001; Poterba and von Hagen, 1999). A common theme in this literature is that political

\footnotetext{
${ }^{7}$ In a paper complementary to ours Gagliarducci et al. (2009) test for the accountability of politicians elected under different electoral systems in Italy's mixed proportional system.
} 
fragmentation, measured, for example, by size of the legislature or number of parties in the government, increases overall spending and deficits. ${ }^{8}$ We contribute to this literature because we can test for the first time whether the effects of political fragmentation (in the legislature) differ by electoral system. ${ }^{9}$

\section{Historical Background ${ }^{10}$}

Before 1890, all cantons in Switzerland had a plurality system in place. ${ }^{11}$ Between 1890 and 1992 , twenty-three out of the twenty-five cantons switched to proportional representation. ${ }^{12}$ The first column of table 1 shows the year when each canton first elected the legislature under the new rule. In 2000, only two cantons, Appenzell-Innerrhode and Grisons, still rely exclusively on plurality rule. A few cantons (see column (2) of table 1) use a mixed proportional system, which we code as a proportional system. For example, in 1992, Uri adopted the proportional system in districts with more than two mandates, i.e. about three-quarters (or 47 out of 64 ) of its voting districts. However, the results are not sensitive to this classification (see section 5.4). We next discuss which forces led to the large-scale constitutional reforms in the cantons over the past century.

\footnotetext{
${ }^{8}$ We abstract from fragmentation of the executive here because we do not know the party composition of the executive only its overall size. Further, we observe few changes in the size of the executive which will be absorbed by canton fixed effects. Finally, the executive in each canton is directly elected over most of our period and hence little affected by electoral reform of the legislature, which is the focus of this article.

${ }^{9}$ We also show that the rising political influence of left-wing parties is associated with more government. While this association has been documented for the post-war period (see, Blais et al., 1993; Pettersson-Lidbom, 2008; Tavares, 2004), we establish this link over a much longer time period - ever since the working class became a relevant political force in Switzerland in the late nineteenth century.

${ }^{10}$ This section builds on Gruner (1977), Klöti (1901), Saripolos (1899) and Vatter (2002). Detailed discussions of the Swiss electoral system can be found in Garrone (1991), Giacometti (1941), Kölz (1987), Lutz and Strohmann (1998), Moser (1987) and Poledna (1988).

${ }^{11}$ A few cantons (for example, Geneva) exclusively relied on plurality rule where the candidate with the largest share of votes in each district is elected. Most cantons however rely on a mixture of majority and plurality rule. Hence, the absolute majority of votes (50 percent) is required in the first round, while in the second round only the relative majority among the remaining candidates is needed to win a seat.

${ }^{12}$ The canton Jura was founded in 1978 and hence is excluded from the analysis.
} 


\subsection{Political Conflict and the Struggle for Electoral Reform}

Switzerland's population has been divided into Catholics and Protestants ever since the Reformation. This ideological split led to violent clashes, for example, the war in 1847 (Sonderbundskrieg) and the cultural conflict (Kulturkampf) of the 1870 s. ${ }^{13}$ In the political arena, the rift was mirrored in the longlasting struggle between conservative forces supported by the Catholic population and the liberal-radical movement backed by the Protestants. Only in a few cantons was one party able to maintain political dominance over a prolonged period of time. In many other cases, alternating majorities and often temporary coalitions between liberal and conservative groups were the rule rather than the exception.

The social changes following industrialization added a new dimension to the existing conflict. As in many European countries, industrialization saw the rise of a sizeable working class, especially in the urban centers. Though industrialization in Switzerland occurred early in the century, it was not until the second half of the nineteenth century that workers became politically organized. The Social-Democratic party first emerged in 1850, building on earlier voluntary associations (Grütlivereine). Yet, the workers' candidates were rarely able to secure a majority of votes under plurality rule; and even if they did, they never achieved a majority of seats (Gruner, 1977; 1978).

In this climate of political conflict and unstable majorities, the new system of proportional representation promised to accommodate the diverging political interests and to generate a more stable political environment (see the contemporaneous discussion in Klöti, 1901 and Saripolos, 1899). The prevalence of plurality voting also came increasingly under scrutiny as ruling parties manipulated voting registers to secure their vulnerable political positions. It was common practice, for example, not to count out-ofcanton migrants as part of a canton's population, which lowered the number of representatives elected in rapidly growing urban districts. ${ }^{14}$ Here, proportional representation suggested a compromise in the

\footnotetext{
${ }^{13}$ While the conflict in 1847 largely took place between Catholic, conservative cantons (Appenzell-Innerrhode, AppenzellOuterrhode, Uri, Schwyz, Obwalden and Nidwalden) and those with Radical-liberal governments, there were also violent conflicts between the two groups in Fribourg, Lucerne, Valais and Zug (Vatter, 2002). The cultural conflict of the 1870s between the Catholic church and the state involved the educational responsibilities and privileges of the Catholic church.

${ }^{14}$ Unlike present debates about plurality systems, gerrymandering, i.e. the manipulation of district boundaries by politicians was not an issue in the Swiss cantons at the time. The reason is that voting districts are tied to historical political units, especially communities and county boundaries (Bezirke or Kreise). Furthermore, number and boundaries
} 
acrimonious battle over the assignment of seats to voting districts.

\subsection{Explaining the Pattern of Electoral Reform}

Understanding the determinants of electoral reform in the cantons is important for evaluating the validity of our empirical strategy. The discussion in the last section suggests a set of common factors driving electoral reform. First, conflicts arising between two, equally strong parties backed by religious differences were an important motor in the early adopting cantons. The first adopters of proportional representation illustrate this point. In Ticino (adoption in 1891), plurality rule and fixed voting districts produced an increasingly unequal distribution of seats, which led to violent street fights. The conflict escalated to the point where the federal government intervened and mandated proportional representation. In Geneva (adoption in 1892), changing majorities in each of the three districts generated unstable electoral outcomes which again resulted in fierce conflict.

In contrast, industrialization and the rise of left-wing parties played an important role in many cantons adopting between 1900 and 1945 (e.g. the city cantons Basle or Zurich). Here, electoral reform was often pushed on the political agenda by a coalition of new left-wing parties and existing minority parties, which hoped to improve their political position. ${ }^{15}$ After 1950, proportional representation was typically introduced when cantons abolished their communal meetings (Landsgemeinden) in favor of more representative forms of government.

These common factors driving electoral reform could potentially influence public spending decisions directly. For example, conflict between heterogeneous groups might lower spending if the groups disagree about the provision of public services (see Alesina et al., 1999). Similarly, the rising working class might have a higher demand for government services like clean water or unemployment insurance. To account for these influencing factors, we control in all our specifications for religious (and linguistic) heterogeneity

of voting districts are typically fixed in the canton constitutions and hence, any changes require approval by the electorate in a referendum.

${ }^{15}$ It might have been the specific balance of power among established parties rather than the mere political threat posed by left-wing parties that favored electoral reform in the early twentieth century (Lutz and Zila, 2007). 
and the size of the industrial sector. Furthermore, we show that the strength of direct democracy does not affect our estimates.

Beyond these factors, there seems little systematic pattern of adoption. For example, we find no evidence that certain geographic regions were more likely to adopt proportional representation than others. Figure 1 shows that many cantons that switched prior to 1919 (when proportional representation was adopted for federal elections) are located in the East (lighter shade). But so are the two cantons that still rely exclusively on plurality rule (dark color). We discuss the plausibility of our identification strategy in more detail in section 4.2. and further probe its validity in section 5.4 and 6 .

\subsection{Political Consequences of Electoral Reform}

The adoption of proportional representation had immediate effects on the composition of canton parliaments. Parties dominant under plurality rule typically experienced a decline in their number of seats in parliament. ${ }^{16}$ For example, the seat share of the Radicals in Solothurn dropped from 85 percent to 62 percent in the first election under proportional rule in $1895 .{ }^{17}$ Instead, the number of parties with seats in the legislature increased from on average 3.5 to 4.3 parties in the new proportional system. This development was in part driven new parties as existing organizations split into several factions or previously unorganized groups founded new political parties after electoral reform.

Moreover, previously excluded or underrepresented groups now gained legislative representation in proportion to their popular support. Left-wing parties immediately increased their political weight in many canton parliaments. On average, their share of seats rose from 7.1 percent under the old system to 19.7 percent under proportional system (t-statistic: 17.4). There are however large differences across cantons: left-wing seats quadrupled in Basle City (from 7 percent to 28 percent) and other cities like

\footnotetext{
${ }^{16}$ This raises the question of why dominant parties under plurality rule would ever agree to electoral reform. The exploration of this question is beyond the scope of this paper and left for future research (see also Lutz and Zila, 2007; Ticchi and Vindigni, 2010).

${ }^{17}$ An alternative way to assess changes in representation under the proportional system would be to calculate the proportionality between number of votes and seats in the legislature (see Besley and Preston, 2007). Unfortunately, we do not have data on vote shares of parties in canton parliaments available to us before the switch to proportional representation.
} 
Zurich or Lucerne. Left-wing parties in contrast did never play an important role in more rural cantons like Nidwalden, Zug or Valais.

\section{Data and Empirical Strategy}

\subsection{Data}

To analyze the consequences of the shift to proportional representation, we assembled a rich new data set for all Swiss cantons between 1890 and 2000. For each canton, we collected information on government expenditures and revenues, the electoral system and socio-demographic characteristics. Data on fiscal policy and canton characteristics are compiled from Historical Statistics of Switzerland (RitzmannBlickenstorfer, 1996), multiple volumes of the Statistical Yearbook of Switzerland, and the Swiss decennial Census. A detailed description of the data sources is provided in Appendix A, and a separate web appendix is available from the authors.

We extracted information on the electoral system and other political institutions by examining all past and current canton constitutions and relevant electoral laws. We complemented and cross-checked this information with cantonal archives (personal communication) and secondary sources (Lutz and Strohmann, 1998; Klöti, 1901; Schoop, 1987; Société d'histoire et d'archéologie du canton de Neuchâtel, 1989; Wicki, 2006). The institutional measure for the electoral rule in canton parliaments is a binary indicator, which takes a value of one if a canton has a proportional or mixed proportional rule and zero if plurality rule is in place. ${ }^{18}$ When a canton switches from plurality rule to proportional representation, the indicator is zero until the first election took place under the new rule. It is one in the year of the first election under proportional representation and all years thereafter.

Our main outcome variables are the log of canton expenditures and revenues per capita in a given year. Both are available annually over the entire period. To analyze whether proportional representation

\footnotetext{
${ }^{18}$ Note that our estimates should be interpreted as the combined effect of electoral rule and district magnitude since cantons using proportional rule also have a smaller number of voting districts.
} 
increases the provision of spending for large segments of the population, we collected information on expenditures for education and welfare. The cantons bear the sole responsibility for secondary education, which is predominantly provided publicly. Spending on welfare includes social assistance to the poor and social security payments. Our measure of welfare spending contains strong elements of insurance against poverty and provisions for old age which benefit a large share of the population. Data on welfare are available since 1930, data on education expenditures since 1890.

To test whether spending in plurality systems is targeted toward geographic constituencies, we compiled data on expenditures for roads and subsidies to agriculture. Spending on canton roads can be easily targeted geographically while agricultural activities are highly concentrated in certain regions. Agricultural subsidies are available since 1930 and expenditures for roads since 1925. Education and welfare expenditures are measured per capita, while expenditures for roads and agricultural subsidies are expressed per 1,000 inhabitants. ${ }^{19}$ All expenditure and revenue variables are deflated to Swiss Francs in 2000. Information on the electoral rule is only available in election years while expenditures and revenues are recorded annually. For non-election years, we assign the electoral rule used in the last parliamentary election. The annual panel allows us to evaluate the effect of the electoral system on government spending in both election and non-election years.

We complement the panel with Census data on the social, demographic and economic conditions, e.g. the age structure, population size and the share of people living in cities above 10,000 inhabitants. We also have information on the importance of industrialization, calculated as the percentage of the workforce that is employed in manufacturing and agriculture. We control for population heterogeneity by calculating Herfindahl indices for three religions (Protestant, Catholic and Jewish) and three linguistic groups (French, Italian and German-speaking). Our fragmentation measure, calculated as one minus the Herfindahl index, is closer to zero if one group dominates and approaches one if the groups are equal

\footnotetext{
${ }^{19}$ Our observed spending categories do not sum to total expenditures as several categories (e.g. spending on administration, law enforcement, public transport or water and sewer services) are not available in the early decades of the 20th century.
} 
in size. ${ }^{20}$ Religious and linguistic heterogeneity are both substantial in Switzerland ranging from zero to 0.76 and 0.87 respectively. Finally, we collected further details of the political system from the canton constitutions: the size of parliament, the electoral cycle, the introduction of women's suffrage, direct democratic participation rights and whether the president of the executive is directly elected. Table 2 shows summary statistics of all variables used in the empirical analysis.

\subsection{Empirical Strategy}

Exploiting the geographic and temporal variation in the adoption of proportional representation after 1890, we use a difference-in-difference approach to estimate its effect on public spending. More specifically, for canton $c$ in year $t$, we estimate models of the form:

$$
Y_{c t}=\alpha_{c}+\gamma_{t}+\beta \text { Prop }_{c t}+\delta^{\prime} X_{c t}+u_{c t}
$$

where $Y_{c t}$ denotes the log of annual expenditures per capita in a specific policy area. The variable Prop $_{c t}$ represents the electoral system. The variable is a binary indicator equal to zero as long as the legislature is elected according to plurality rule. The indicator switches to one when the parliament is first elected according to proportional rule, and all years thereafter. The parameter of interest in equation (1) is $\beta$.

Our specifications also include canton $\left(\alpha_{c}\right)$ and year $\left(\gamma_{t}\right)$ fixed effects. Year fixed effects absorb common shocks such as the two World Wars or economic depression. Canton fixed effects are important because there are strong, persistent differences between German-speaking and French- or Italianspeaking cantons. For example, our detailed study of canton constitutions reveals that some cantons allow their citizens to recall the government, while others do not. These institutional differences are highly persistent over time and we expect them to influence politicians' behavior.

Because Swiss cantons might differ along other dimensions, we further include a number of time-

\footnotetext{
${ }^{20}$ For example, if the shares of the three groups are $0.3,0.3$ and 0.4 , then the Herfindahl index is 0.34 and our measure of fragmentation 0.66. If their shares are $0.1,0.1$ and 0.8 instead, the Herfindahl index is 0.66 and the measure of fragmentation 0.34 .
} 
varying variables $X_{c t}$. To control for differences in the demand for government services, we add the age structure of the population and the size of the urban population. Population size is included to allow for economies of scale in the provision of public services. Federal subsidies adjusts for differences in the resources available to cantons.

One variable that is not available in our data set is canton income (or wages). We use several variables to adjust for differences in wealth: the percentage of the population owning a car, the number of physicians per 1,000 population and the infant mortality rate. The three variables alone explain 43 percent of the variation in canton income between 1965 and 2000 when we have income data available. Once we include our other controls and canton and year fixed effects, we can account for 93 percent of the variation in canton income. Hence, the absence of a direct income measure is not a major limitation of our study.

In our econometric framework, the timing of adopting proportional representation is assumed to be uncorrelated with the error term conditional on all our control variables. Is this identifying assumption plausible? We have come to the conclusion that our identification strategy is plausible given the evidence in section 5 and 6 . Our detailed study of the history in the individual cantons (see section 3) revealed that industrialization and population heterogeneity are important forces driving electoral reform. Hence, all our specifications include measures of religious and linguistic fragmentation and the size of the industrial sector. $^{21}$ We also find no evidence that related political reforms like women's suffrage, differences in direct democratic institutions or other political events affect our results. Further, fixed differences across states and common shocks in government spending are all purged from the estimate of $\beta$. In the robustness analysis, we allow for canton-specific linear trends and more flexible canton-specific decade dummies that purge our estimate of $\beta$ from all linear unobservable canton trends and even nonlinear canton-specific shocks. These flexible specifications, like extensive tests to capture the dynamics and

\footnotetext{
${ }^{21}$ One concern might be that proportional representation itself affects population heterogeneity through selective migration. In that case, our specification would capture only the effect of proportional representation net of its impact on population heterogeneity. Empirically however, we do not find that proportional representation is associated with changes in population heterogeneity or internal migration in the decades after adoption.
} 
serial correlation in our spending variables, leave our results unchanged. We probe the validity of our identifying assumption further in section 5.4. below and corroborate our findings using exogenous variation at the local level in section 6 .

\section{Canton-level Results}

\subsection{Broad Services and Targeted Transfers}

We first test whether politicians shift to spending with broad benefits after proportional representation is adopted. Our measures for broad spending are the log of expenditures for education and welfare. The first specification includes the proportional variable, our set of canton controls and year effects. The second specification also includes canton fixed effects to absorb permanent differences in political structure and preferences for government across cantons. The results in Table 3 show that proportional systems spend more on goods with broad constituencies: cantons that adopted proportional representation spend 10 percent more on education (column (2)) and 33 percent more on welfare (column (4)) than under plurality rule.

The control variables have the expected sign. More subsidies from the federal level have a positive effect on education and welfare spending. Urbanization is associated with more welfare spending but also less education spending. The latter may reflect economies of scale in the provision of schools in densely populated areas. The coefficient on log population is strongly negative in the fixed effects specification, suggesting substantial economies of scale in the supply of education. With respect to ethnic and religious fragmentation, we find conflicting results: linguistic heterogeneity reduces spending on education but religious heterogeneity increases it. One explanation is that the French-, Italian- and German-speaking populations have different preferences for public services, which makes it difficult to reach a political agreement about their provision (Alesina et al., 1999).

Our second empirical test is whether spending on geographically concentrated goods declines after 
the adoption of proportional representation. The dependent variables are now the log of expenditures for roads and agricultural subsidies. The control variables are the same as before. The right-hand side of table 3 shows that expenditures for roads are indeed 53 percent lower (column (6)) while agricultural subsidies are 28 percent lower (column (8)) when parliaments are elected under proportional rule.

In sum, our estimates show that the adoption of proportional rule shifted the scope of public spending away from locally targetable transfers toward spending for broad social groups. Our results extend previous findings from cross-country data that countries with a proportional system have more social spending than countries with a plurality system (Milesi-Ferretti et al., 2002; Persson and Tabellini, 2003). While our estimated coefficients seem large, the effects are actually smaller than previously found. For example, Persson and Tabellini (2003) report that social security and welfare spending (measured relative to GDP per capita) are 2 to 3 percent higher in countries with proportional system. Our estimate of 33 percent higher welfare spending in cantons with proportional rule is equivalent to a 1 percent higher spending on welfare plus social security (in terms of GDP per capita in 2000). The findings confirm that the adoption of a proportional system change the electoral incentives of representatives: they rely less on local groups but rather seek the support of broad social groups even if these are geographically dispersed.

\subsection{Size of Government}

As discussed above, the effect of proportional rule on the overall size of government is theoretically ambiguous. We estimate the same model in (1) where the dependent variable is now the log of total expenditures or total revenues per capita. The results are reported in table 4. Column (1) shows that cantons switching to proportional representation have 4 percent higher expenditures than cantons with

a plurality rule. The same pattern emerges on the revenue side where cantons with proportional rule have 2.8 percent higher expenditures, though the coefficient is not statistically significant.

Once we rely on within canton variation, we find that proportional representation is not associated 
with any change in expenditures (column (2)). ${ }^{22}$ Proportional rule does however, lower government revenues by 2.8 percent though the coefficient is only marginally significant (column (4)). These results of similar spending patterns but fewer revenues suggests that parliaments elected under the proportional rule are more likely to run deficits.

The control variables in both the expenditure and revenue regressions have the expected signs. Federal subsidies, an important source of revenues, are again associated with higher spending. Population size (in logs) lowers expenditures which suggests substantial economies of scale. Also, linguistic and religious heterogeneity result in less spending in the fixed effects specification.

Our results on total spending differ from most of the previous findings that are based on crosscountry data. Persson and Tabellini (2003) and Milesi-Ferretti et al. (2002) report positive results for their sample of OECD countries while Aidt et al. (2005) find weakly negative results for Western Europe. If we analyze the cross-section, we also find a positive effect on total spending (see columns (1) and (3) in table 4). Hence, one possible explanation is that permanent differences in political institutions or voter preferences across countries drive the positive correlation between proportional representation and spending found in previous studies.

\subsection{Political Fragmentation and Left-Wing Representation}

Thus far, we have been silent of what mechanism underlies our reduced-form estimates. Economic theory suggests that electoral systems affect not only electoral incentives but also changes the composition of the legislature. This section investigates how these forces influence total spending.

We first examine how proportional representation changes political fragmentation and the left-wing representation in the legislature. We measure fragmentation in three ways: by the number of legislators, the number of parties with seats in the legislature and by party fragmentation. This last measure is calculated from the seat distribution of six different parties; the remaining, smaller parties are collapsed

\footnotetext{
${ }^{22}$ Taagepera and Shugart (1989) argue that election results under proportional rule with very small district magnitudes $\left(\frac{\text { seats }}{\text { districts }} \leq 6\right)$ yield seat shares close to those obtained under plurality rule. In our data however, the vast majority of canton-year observations (85 percent) have a district magnitude of six or higher under proportional representation.
} 
into a single category ('other'). Hence, we will underestimate the actual degree of political fragmentation in canton parliaments. Party fragmentation is then calculated as one minus the Herfindahl index of concentration; it varies from zero to one, with larger values indicating a more fragmented party structure.

We also investigate how the political representation of left-wing parties changes with political representation. The variable is defined as the share of seats held by the Social Democrats. Estimates based on all left-wing parties, which includes seats held by the Communist party, are very similar and not reported here. As controls, we include in our regressions population heterogeneity, the share of urbanization and population size measured in logs.

The results are presented in table 5. We find that proportional representation has strong effects on the composition of parliament: it increases party fragmentation by 0.14 or more than one standard deviation and the number of parties by 0.6 or about $6 / 10$ of a standard deviation. In addition, the representation of left-wing parties increases by 6 percent or $1 / 2$ of a standard deviation under proportional representation. The effect on the overall size of the legislature is in contrast small. Parliaments elected under proportional rule have on average 2.4 seats more, which corresponds to a mere $1 / 20$ of a standard deviation. These findings suggest that fragmentation along party lines and the political influence of left-wing parties indeed increases in canton parliaments with proportional representation.

Given these substantial changes in party composition under proportional rule, we next investigate how fragmentation and left-wing representation affect public spending after electoral reform. As a benchmark, the first specification in table 6 reruns the baseline specification from table 3 for the subsample of years and cantons for which we have valid party information. The coefficient on proportional representation is very similar to the one estimated for the full sample for both expenditures (column (1)) and revenues (column (4)).

To uncover the theoretical mechanism, we now add in a first step the measures of legislative fragmentation and left-wing representation to our baseline expenditure and revenue regressions. We expect 
both changes to raise spending overall. In a second step, we then allow the effect of party fragmentation to vary by electoral system. If party discipline and homogenous party platforms reduce the number of actual decision-makers, the effect of party fragmentation would be less pronounced in a proportional system than in a plurality system.

Results for the first step are shown in column (2) and (5) of table 6. As expected, a higher seat share for left-wing parties and also in general party fragmentation increase spending. In contrast, the raw number of parties and legislature size have no effect. Based on the estimates and observed changes with the adoption of proportional representation, we can calculate the relative impact of party fragmentation and left-wing representation. We find that left-wing representation has the strongest correlation with fiscal policy: it increases spending by 6.6 percent $\left(0.511^{*} 0.219\right)$. The overall effect of political fragmentation (independent of the electoral system) is to raise spending by 4.1 percent $\left(0.291^{*} 0.142\right) \cdot{ }^{23}$

In a second step, we now test whether proportional representation reduces the common pool problem associated with party fragmentation. Hence, we include an interaction effect between party fragmentation and proportional representation (shown in column (3) and (6)). ${ }^{24}$ If the effect of political fragmentation is muted in a proportional system, this interaction term should be negative. Strikingly, the coefficient on the interaction term is indeed negative and highly statistically significant. While political fragmentation raises spending by 32.2 percent $\left(0.611^{*} 0.533\right)$ in a plurality system, it has almost no effect in a proportional system $\left((0.611-0.572)^{*} 0.675=2.6\right.$ percent $){ }^{25}$ While party fragmentation is

\footnotetext{
${ }^{23}$ Conditional on the compositional changes in the legislature, the coefficient on the proportional rule is -7.4 percent. One interpretation of the negative coefficient is that the median voter does not value targetable goods a lot. The negative coefficient could also reflect barriers to entry which limit electoral competition in a plurality system and encourage politicians to spend more than in a proportional system. The first explanation is very difficult to test; the second explanation seems somewhat unlikely given the evidence that rent-seeking behavior is less common among politicians elected under plurality rule (see Gagliarducci et al., 2009). Here, we suggest and test a very different explanation: that the effect of party fragmentation is lower in a proportional system because of party discipline and more homogenous party platforms.

${ }^{24}$ We also estimated a specification that allows for interaction effects of proportional rule with left-wing representation, the number of legislators and number of parties. None of these additional interaction effects were statistically significant at conventional levels.

${ }^{25} 0.533$ denotes the mean party fragmentation in a plurality system and 0.675 the respective value in a proportional electoral system.
} 
substantially higher under proportional rule, we find no overspending bias associated with it. ${ }^{26}$ Further, once we allow for the differential effects of party fragmentation, the coefficient on the proportional rule is positive though only borderline significant. This is consistent with less intense electoral competition in a proportional system (see the related evidence in Gagliarducci et al., 2009).

In sum, we find strong evidence that party fragmentation and the share of seats for left-wing parties increases after the adoption of proportional representation. Overall, both changes lead to more spending. The offsetting factor is that party fragmentation has little impact on spending in a proportional system. The net effect of these forces is that overall government size does not change after the switch to proportional representation (the sum of all effects is a mere 0.2 percent higher spending).

\subsection{Informal Validity Tests and Robustness Checks}

Natural concerns with this paper's empirical strategy include potential biases arising from serial correlation and dynamics in the spending variables, the possibility of endogenous adoption of proportional representation and the influence of other political events that are confounded with proportional representation. This section presents a range of informal validity tests and robustness checks that investigate, but fail to corroborate these concerns.

First, our reduced-form estimates in table 3 and 4 would be biased if persistent spending shocks, e.g. during the economic depression or the two World Wars, are correlated with the decision to adopt proportional representation. To address this issue, we implement a number of dynamic panel estimators to account for serial correlation and spending dynamics (shown in table A1). First, we add the lagged dependent variable as an additional control. While specifications with lagged dependent variable and fixed effects are typically biased, this bias should be small in our case because the number of time periods ( $T=110$ years $)$ is large relative to the number of cross-sectional units $(N=25$ cantons). Alternatively, we implement the Arellano-Bond estimator for dynamic panel data (row (2)). Both dynamic panel

\footnotetext{
${ }^{26}$ Unfortunately, we cannot test with our historical data whether this result is driven party discipline in actual policymaking or by the convergence of party platforms during the electoral stage. However, we think that uncovering this differential effect of political fragmentation is of interest in its own right.
} 
specifications yield similar results to our baseline estimates. An alternative way to control for serial correlation is to use spending changes as our dependent variable. The estimates for spending changes in row (3) are substantially weaker, but again qualitatively similar. If all spending variables exhibit the same type of nonstationarity, we can eliminate nonstationarity in the data by using spending shares. Again, our results based on spending shares as dependent variables (row (4)) are very similar.

Second, our standard errors may be severely downward biased if spending is highly persistent (Bertrand et al., 2004). In view of our relative small number of cantons, we implement the before-after estimator suggested by the authors. We regress spending net of all control variables on the dummy for proportional representation for the sample of cantons that adopted the new electoral system. While the standard errors in row (5) of table A1 are somewhat larger than in the baseline, the statistical significance of our estimates is not affected.

Third, we investigate if our results are driven by unobserved political liberalization rather than the actual adoption of proportional representation. In that case, we should observe detectable spending adjustments during reform attempts that did not ultimately result in the adoption of proportional representation. Hence, we rerun our estimation in table 3 and 4 using the years of failed reform attempts rather than our indicator for proportional rule as our main independent variable. The placebo experiment shown in table A2 in the appendix shows that failed initiatives (columns (1) and (2)) and failed parliamentary petitions (columns (3) and (4)), with one exception, do not explain changes in expenditures.

Fourth, we test whether the timing of adoption is related to socio-economic conditions (population size, population heterogeneity, employment and age structure, labor force participation, federal subsidies) or other democratic reforms (direct election of executive, adoption of direct democratic participation rights, founding of social-democratic party in the canton) in 1890 when all cantons still have a plurality system in place. Table A3 in the appendix shows that only religious heterogeneity and the existence of a law referendum are associated with an earlier electoral reform. Since we control for 
population heterogeneity in all regressions and test for the influence of the law referendum below, these correlations do not affect our conclusions.

Fifth, we analyze whether our results are driven by unobservable canton trends or exceptional political conditions just prior to electoral reform. For example, a year of intense political conflict between two major parties might result in lower overall spending. To test for the influence of canton-specific events prior to electoral reform, we add dummies for the first, first three and first five years to the baseline specification. The coefficient on the proportional variable is now identified net of spending decisions up to five years prior to the actual reform. Row (1) in table A4 shows that the results remain unchanged. More generally, we could miss unobserved canton-specific trends. We test for this by including canton-specific linear trends (row (2)) and more flexible canton-specific decade dummies (row (3)). The latter specification allows for any unobservable shock to affect cantons differentially, for example, the two World Wars. The results for the individual expenditure categories remain unchanged. For linear trends, the effect on overall spending is positive though only significant at the ten percent level. One interpretation is that spending in non-adopting cantons followed a steeper upward trend than adopting cantons. However, we do not find this pattern for the individual expenditures categories and with the more flexible decade dummies.

Sixth, we check whether other plausible socio-economic or political changes can explain our results. Specifically, we test for the influence of the demand for democratization by including the number of years since the executive has been directly elected and controls for direct democratic participation rights (provisions for the law referendum, budget referendum, the signature requirement for the voter initiative and whether the canton relies on community meetings) in each canton (row (4) in table A4). We also control for the extension of voting rights to women (row (5)) and more broadly the influence of change in social values by adding the divorce rate and share of protestants (row (6)). We further control for other political reforms that could affect spending such as changes in the size of the legislature and executive as well as the electoral cycle (row (7)). The results clearly reveal that controlling for these political, 
institutional and social changes has little effect on our estimates.

Finally, we assess the robustness of our results to alternative specifications of the spending and electoral variables. Row (8) exclude cantons with a mixed proportional system, and row (9) restricts the sample to election years. The last specification uses the level of expenditures as the dependent variable. For all expenditure categories, we find the same effects for the scope of government and no effect on the size of government.

\section{Evidence from Local Governments}

Despite the robustness of our findings, a remaining concern might be that other omitted time-varying unobservables affects both spending and the decision to adopt proportional representation. In this section, we use exogenous variation at the local level in Switzerland to show that these concerns are unwarranted. Using a variety of empirical strategies, we again find no effect of proportional representation on local public spending.

\subsection{Electoral Systems and Data at the Local Level}

Local communities in Switzerland provide a unique setting to analyze the effect of proportional representation. The roughly 3,000 communities enjoy substantial fiscal autonomy: a local income tax provides an independent source of revenues. They also make important spending decisions in the areas of primary schooling, welfare and other local services (fire, police, garbage collection etc.).

Their fiscal autonomy notwithstanding, Swiss communities are restricted in their choice of electoral systems. Many cantons impose mandates for local elections: some mandate proportional rule, others plurality rule. Since these mandates are set at the canton level, they are exogenous from the perspective of the individual community. Furthermore, mandates have been in place for a long time and have proved difficult to change. Ticino and Zug, for example, mandate proportional representation at the local level since 1891 and 1894 respectively. As such, canton mandates are not influenced by current local finances 
or socio-economic conditions correlated with local public finances.

Our first empirical strategy compares the size of government in communities where proportional representation is mandated to spending in communities where plurality rule is mandated. This analysis relies on a comparison of communities across cantons with different mandates. Our second empirical strategy compares communities in cantons that do not impose mandates. Using a matching estimator, we compare spending in communities with plurality rule to those with proportional rule. Since this approach allows us to compare similar communities located in the same canton, we control for unobservable differences across cantons.

We base our analysis on a survey of each community's head administrator in four different years $\left(1988,1994,1998\right.$ and 2005). ${ }^{27}$ The survey asks detailed information on the political structure of local governments. The response rate in each wave is over 75 percent. As our measure of local spending, we use the number of administrative personnel per capita. Administrative spending captures genuine differences in the size of government because the provision of public goods and services require a bureaucracy for administration. Further, wasteful spending or rents for local politicians are often associated with more bureaucracy. Finally, administrative expenditures are highly correlated (0.8) with the overall size of government at the canton level.

The typical community has two levels of local government: the executive and legislative. The executive (often called Gemeinde- or Stadtrat) is the most important political body. It has on average six members and is directly elected by the electorate. ${ }^{28}$ Only about 20 percent of communities have a parliament as their legislative body; all others rely on community meetings of its citizens instead. To avoid a highly selected sample, we study the influence of the electoral rule for the legislature and executive. ${ }^{29}$ The effect of proportional rule on fiscal policy should be qualitatively similar for the two

\footnotetext{
${ }^{27}$ We are very grateful to Professor Ladner from the University of Berne for making the data available to us. Details of the survey, questionnaires and data are available at http://www.andreasladner.ch/gemeindeforschung/. An in-depth description of the data can be found in Ladner (1991) and Ladner et al. (2000).

${ }^{28}$ Only in Neuchatel, the executive is elected by local parliaments.

${ }^{29} \mathrm{~A}$ second reason to include the executive is that we only have information on the electoral rule for the legislative in 1988. Though we contacted all communities with a parliament by email to request information on their electoral system after 1988, the response rate was only around 30 percent.
} 
political bodies (see, for example, Persson and Tabellini, 2003).

We code mandates from each canton's constitution, additional laws on local affairs and information in Ladner (1991). Our main variable of interest is a binary indicator equal to one if a canton dictates proportional rule and zero if majority rule is mandated. We calculate this variable separately for the executive and legislature. Since electoral rules and mandates in particular are persistent over time, our estimates rely on variation across communities for identification. ${ }^{30}$

To control for observable community characteristics, we match our survey to information from the 1980, 1990 and 2000 Swiss census. Census data provides information on the size of the community, its age structure, the employment rate, the fraction employed in agriculture or industry, the share of protestants and whether the community is located in the Alps. We used linear interpolation to create annual observations and kept the observations from the survey years for the analysis. Table 7 reports summary statistics for our local data.

\subsection{Results from Mandates and Matching}

We first compare spending in communities that are subject to canton mandates. Specifically, we compare the size of local administration in communities with mandated proportional rule to communities with mandated plurality rule. Sixteen cantons mandate plurality rule for the executive, while two cantons mandate proportional representation. We cannot perform a similar analysis for the legislative as no canton mandates plurality rule. Because mandates are imposed at the canton level and persistent over time, they are exogenous from the perspective of the individual community.

We estimate a regression model similar to (1), where the dependent variable is administrative personnel per capita in a community (in logs). ${ }^{31}$ To control for observable differences, we include year dummies,

\footnotetext{
${ }^{30}$ Between 1988 and 2005, two cantons abolished their mandate for majority rule (Appenzell-Innerrhode in 1996 and Lucerne in 2004). In the two cases, the canton mandate is one before the change and zero thereafter.

${ }^{31}$ We choose the log specification to be consistent with our canton estimates. In the raw data, the number of administrators is zero for about 5 percent of the sample $(\mathrm{N}=431)$. The zeros seem to be actual zeros only in the small number of communities with a population below 200. In larger communities, the zeros are likely to be missing values. For the log specification, we dropped communities with no reported administrator. We find, however, similar results if we reestimate the relationship in levels.
} 
the fraction of children under 15, detailed controls for population size, the share of protestants, the fraction of nonemployed and employees in agriculture or mining. We also add the dominant language of the canton, and whether the community is located in the mountains to adjust for time-invariant cultural and geographic heterogeneity. Standard errors are clustered at the canton level.

Our benchmark estimates (columns (1) and (2)) in table 8 show the relationship for all communities that choose their electoral rule. We find no statistically significant correlation between the size of public administration and the electoral rule for the legislature (column (1)) or the executive (column (2)). A comparison of the first two columns confirms our earlier intuition that the electoral rule has similar effects irrespective of the political body (legislature or executive). These results are also consistent with the zero effect found at the canton level.

Next, we estimate the same regression for communities with mandated electoral rule for the executive. The main independent variable is a binary indicator equal to one if the community has mandated proportional rule to elect its executive and zero if plurality rule is mandated. Column (3) shows that communities with mandated proportional rule do not have larger local administrations than communities with mandated plurality rule. ${ }^{32}$ However, we might still be concerned that cantons with mandated proportional rule differ from cantons with mandated plurality rule along some other unobservable dimension.

To address this concern, we further restrict the analysis to communities located close to the border between cantons with different mandates. Ticino (a canton mandating proportional rule) is located South of Uri (a canton mandating plurality rule). Using GIS maps to identify border communities, we compare communities located at the Northern border of Ticino with communities located at the Southern border of Uri. We use the same approach to match communities in Zug to communities in Aargau, Lucerne, Schwyz and Zurich. To the extent that unobservables change smoothly with

\footnotetext{
${ }^{32}$ The results remain unchanged if we add controls for a local parliament or additional demographic variables to the specification. Results are similar if we drop the two cantons that abolished their mandates; they are also unchanged if we exclude cities with more than 30,000 inhabitants, which tend to have more than one voting district. Results are available upon request.
} 
geographic distance (and are uncorrelated with canton borders), the sample of border communities yields unbiased estimates. Reassuringly, we find that communities separated only by a canton border have very similar socio-demographic characteristics. Estimation of the same relationship on our sample of border communities again shows no statistically significant relationship between electoral rule and the size of public administration (column (4) in table 8).

Another way to address the concern of unobserved differences across cantons is to rely on comparisons within the same canton. Hence, we repeat the estimation with communities located in cantons without mandates on local elections (Berne, Fribourg, Solothurn, Basle County, Grisons, Thurgau, Valais and Jura). Here, we eliminate unobservable permanent heterogeneity across cantons because we compare only communities that lie in the same canton. In a first step, we estimate a logit model of choosing proportional representation to control for observable differences between communities choosing different electoral rules. The predictor variables are the same as those used in the regressions above. We then implement propensity score matching to match communities with similar observable characteristics in the same canton but different electoral rules (under the assumption that the control variables eliminate selection bias). The results of the logit model and the implied treatment on the treated effects are reported in table 9. For both the legislature (column (1)) and executive (column (2)), we find no evidence that communities with proportional rule have more local administration than their matched counterparts.

In sum, the evidence from local governments using mandates and matching confirms our findings at the canton level: proportional representation for the parliament or the executive does not generate bigger governments.

\section{Conclusion}

Using variation in the adoption of proportional representation across cantons and electoral mandates for local governments in Switzerland, this article demonstrates that electoral systems have important 
implications for fiscal policy. Under proportional rule, politicians need the support of broader segments of the population. Accordingly, public spending shifts away from targeted subsidies for narrow groups and encourages spending on broad services like education.

Our findings do not support concerns that proportional rule results in larger governments. Across a variety of methods and levels of government, we find little evidence that proportional representation increases overall spending. We present novel evidence for the theoretical mechanism driving these results. Stronger representation of left-wing parties increase public spending. In contrast, party fragmentation, though higher with proportional rule, has little effect on spending in proportional systems. This result is consistent with recent models that stress party discipline and convergence of policy platforms in a proportional system. Both party discipline and homogenous party platforms reduce the actual number of decision-makers and the variability of political positions which reduce the overspending inherent in plurality systems.

Though pioneering, Swiss cantons were by no means the only political units that adopted the new electoral system. Many countries in Europe and elsewhere switched to proportional representation since 1890; other countries, for example Canada and the United Kingdom, actively debate to adopt it. While Switzerland has, for example, a much stronger direct democratic tradition than other democracies, the effects of proportional representation remain unchanged even conditional on provisions for initiatives and referendums. We therefore believe that our analysis is valid for developed democracies more generally.

Certain features of the Swiss electoral system might however mitigate overspending in a proportional system. Most importantly, voters in Switzerland are able to accumulate votes for a single candidate, which strengthens accountability of politicians. Furthermore, most cantons allow citizens to combine candidates from different party lists ('panachage') rather than choose between closed party lists. As open lists tie the election outcome of individual candidates closer to their performance, this could foster accountability and reduce overspending. An electoral reform that restricts voters to party lists and single, non-transferable votes might be associated with higher spending. Finally, in contrast to pure 
parliamentary systems, Swiss citizens elect the canton executive directly. The independence of the executive might also help to foster spending discipline (see Persson and Tabellini, 2003; Baqir, 2002 for evidence). The Swiss case however clearly demonstrates that it is not proportional rule per se that promotes bigger governments.

\section{References}

[1] Acemoglu, D. (2005), "Constitutions, politics and economics: A review essay on Persson and Tabellini's 'The economic effects of constitutions'." Journal of Economic Literature, 43, 102548.

[2] Aghion, P., A. Alesina, and F. Trebbi (2004), "Endogenous Political Institutions." Quarterly Journal of Economics, 119, 565- 612.

[3] Aidt, T.S.; J. Duta and E. Loukoianova (2006), "Democracy comes to Europe: Franchise extension and fiscal outcomes 1830-1938." European Economic Review, 50, 249-83.

[4] Alesina, R., R. Baqir and W. Easterley (1999), "Public goods and ethnic divisions." Quarterly Journal of Economics, 119, 613-46.

[5] Alesina, A. and R. Perotti (1995), "The political economy of budget deficits." IMF Staff papers, 42, 1-31.

[6] Austen-Smith, D. (2000), "Redistributing income under proportional representation." Journal of Political Economy, 108, 1235-69.

[7] Austen-Smith, D. and J. Banks (1988), "Elections, coalitions and legislative outcomes." American Political Science Review, 82: 405-22.

[8] Baqir, R. (2002), "Districting and government overspending". Journal of Political Economy, 110, $1318-54$.

[9] Bawn, K. and N. Rosenbluth (2006), "Short versus Long Coalitions: Electoral Accountability and the Size of the Public Sector." American Journal of Political Science, 50, 251-65.

[10] Besley, T. and I. Preston (2007), "Electoral bias and policy choice: Theory and evidence", Quarterly Journal of Economics, 122: 1473-1510.

[11] Bertrand, M., E. Duflo and S. Mullainathan (2004), "How much should be trust difference-indifference estimates." Quarterly Journal of Economics, 119, 249-275.

[12] Blais, A.; D. Blake and S. Dion (1993), "Do political parties matter? Parties and the size of government in liberal democracies." American Journal of Political Science, 37: 40-62.

[13] Blum, R. (1980), Erich Klötzlis Landratsjahre. Ein Brevier über das Parlament des Kantons BaselLandschaft. Liestal: Büro des Landrates des Kantons Basel-Landschaft. 
[14] Bradbury, J. C. and W. M. Crain (2001), "Legislative organization and government spending." Journal of Public Economics, 82, 309-25.

[15] Bundesamt für Statistik (1891-2000), Statistisches Jahrbuch der Schweiz. Zurich:.Verlag Neue Zürcher Zeitung.

[16] Carey, J.M. and M.S. Shugart (1995), "Incentives to cultivate a personal vote: a rank ordering of electoral formulas," Electoral Studies, 14,4, 417-39.

[17] Chen, J. and N. Malhotra (2007), "The Law of k/n: The Effect of Chamber Size on Government Spending in Bicameral Legislatures." American Political Science Review, 101, 657-76.

[18] Cox, G.W. (1997), Making votes count: Strategic coordination in the world's electoral systems. New York: Cambridge University Press.

[19] Duverger, M. (1954), Political parties: Their organization and activity in the modern state. New York: John Wiley.

[20] Ezrow, L. (2008), "Parties' policy programmes and the dog that didn't bark: no evidence that proportional systems promote extreme party positioning," British Journal of Political Science, $38,479-97$.

[21] Gagliarducci, S., T. Nannicini and P. Naticchioni (2009), "Electoral rules and politicians' behavior: A micro test." mimeo, Bocconi University.

[22] Garrone, P. (1991), L'élection populaire en Suisse. Etude des systèmes électoraux et de leur mise en oeuvre sur le plan fédéral et dans les cantons. Basel and Frankfurt aM.: Helbing und Lichtenhahn.

[23] Giacometti, Z. (1941), Das Staatsrecht der schweizerischen Kantone. Zurich: Polygraphischer Verlag.

[24] Gilligan, T. W., and J. G. Matsusaka (2001), "Fiscal policy, legislature size, and political parties: Evidence from the first half of the Twentieth century." National Tax Journal, 54, 57-82.

[25] Gruner, Erich (1977), Die Parteien in der Schweiz. Berne: Francke Verlag.

[26] Gruner, Erich (1978), Die Wahlen in den Schweizerischen Nationalrat, 1848-1919. Volume 2, Berne: Francke Verlag.

[27] Hofferbert, R.I. (1976), Comparative socio-economic public policy and political data, 1900-60. Ann Arbor, MI: Inter-university Consortium for Political and Social Research, Study number 34.

[28] Junker, B. (1996), Geschichte des Kantons Bern seit 1798. Band III: Tradition und Aufbruch, 1881-1995. Bern: Archiv des Historischen Vereins des Kanton Bern.

[29] Klöti, E. (1901), Die Proportionalwahl in der Schweiz. Geschichte, Darstellung und Kritik. Bern: Kommissionsverlag Schmid und Francke.

[30] Kölz, A. (1987), "Probleme des kantonalen Wahlrechts." Schweizerisches Zentralblatt für Gemeindeund Staatsverwaltung, 88(2), 49-64. 
[31] Ladner, A. (1991), Politische Gemeinden, kommunale Parteien und lokale Politik: eine empirische Untersuchung in den Gemeinden der Schweiz. Zurich: Seismo Verlag.

[32] Ladner, A., D. Arn, U. Friederich, R. Steiner and J. Wichtermann (2000), Gemeindereformen zwischen Handlungsfähigkeit und Legitimation. Research Report, University of Berne.

[33] Lijphart, A. (1990), "The political consequences of electoral laws 1945-85." American Political Science Review, 84, 481-96.

[34] Lijphart, A. (1994), Electoral systems and party systems: A study of twenty-seven democracies, 1945-1990. Oxford: Oxford University Press.

[35] Lindbeck, A. and J. Weibull (1987), "Balanced budget redistribution as the outcome of political competition." Public Choice, 52, 273-97.

[36] Lizzeri, A. and N. Persico (2001), "The provision of public goods under alternative electoral incentives." American Economic Review, 91, 225-45.

[37] Lizzeri, A. and N. Persico (2005), "A drawback of electoral competition." Journal of European Economic Association, 3, 1318-48.

[38] Lizzeri, A. and N. Persico (2009), "Electoral incentives, political risk-taking and policy reform," In: The Political Economy of Democracy, edited by A. Aragone, C. Bevia, N. Schofield, H. Llavador, Fundacion BBVA.

[39] Lüthi, W. (1962), "Die Struktur des Basler Grossen Rates nach politischer Parteizugehörigkeit und sozialer Schichtung.” Basler Zeitschrift für Geschichte und Altertumskunde, 62.

[40] Lutz, G. and N. Zila (2007), "Explaining the introduction of proportional representation in the Swiss cantons: the role of non-strategic actors and unfair electoral competition." mimeo, University of Berne.

[41] Lutz, Georg and D. Strohmann (1998), Wahl- und Abstimmungsrecht der Schweizer Kantone. Berne: Haupt.

[42] Milesi-Ferretti, G-M., R. Perotti and M. Rostagno (2002), "Electoral systems and the composition of public spending." Quarterly Journal of Economics, 117, 609-57.

[43] Moser, C. (1987), Aspekte des Wahlrechts in den Kantonen. Materialien zur schweizerischen Politik. Nr.1, Berne.

[44] Myerson, R. (1993), "Effectiveness of electoral systems in reducing government corruption: a gametheoretic analysis." Games and Economic Behavior, 5, 118-32.

[45] Norris, P. (2004), Electoral engineering: voting rules and political behavior. Cambridge: Cambridge University Press.

[46] Persson, T. and G. Tabellini (2003), Economic effects of constitutions. Cambridge, MA: MIT Press.

[47] Persson, T., G. Roland and G. Tabellini (2007), "Electoral rules and government spending in parliamentary democracies." Quarterly Journal of Political Science, 2, 155-88. 
[48] Pettersson-Lidbom, P. (2008), "Do parties matter for economic outcomes: A regressiondiscontinuity approach." Journal of the European Economic Association, 6, 1037-1056.

[49] Poledna, T. (1988), Wahlrechtsgrundsätze und kantonale Parlamentswahlen. Zurich: Schulthess.

[50] Poterba, J. and J. von Hagen (1999) (eds), Fiscal institutions and fiscal performance. Chicago: Chicago University Press.

[51] Rae, D. (1967), The political consequences of electoral laws. New Haven: Yale University Press.

[52] Ritzmann-Blickenstorfer, H. (1996), Historische Statistik der Schweiz. Zurich: Chronos.

[53] Rokkan, S. (1970), Citizens, elections, parties: Approaches to the comparative study of political development. Oslo: Universitetsforlaget.

[54] Saripolos, N. (1899), La Démocratie et l'élection proportionelle: Étude historique, juridique et politique. Paris: Arthur Rousseau.

[55] Schoop, A. (1987), Geschichte des Kantons Thurgau. Volume 1-3, Frauenfeld : Huber.

[56] Schuppli, P. and R. Studer (2004), "Deflating Swiss prices over the last five centuries." mimeo, University of Oxford and Berne.

[57] Société d'histoire et d'archéologie du canton de Neuchâtel (1989), Histoire du pays de Neuchâtel. Volume 3, Hauterive : Editions Gilles Attinger.

[58] Taagepera,R. and M.S. Shugart (1989), Seats and votes: the effects and determinants of electoral systems. New Haven, CT: Yale University Press.

[59] Tavares (2004), "Does right or left matter? Cabinets, credibility and fiscal adjustments." Journal of Public Economics, 88, 2447-2468.

[60] Ticchi, D. and A. Vindigni (2010), "Endogenous Constitutions", Economic Journal, forthcoming.

[61] Vatter, A. (2002), Kantonale Demokratien im Vergleich. Opladen: Leske \& Budrich.

[62] Weingast, B., K. Shepsle and C. Johnson (1981), "The political economy of benefits and costs: a neoclassical approach to distributive politics." Journal of Political Economy, 89, 642-64.

[63] Wicki, D. (2006), Der aargauische Grosse Rat, 1803-2003. Wandel eines Kantonsparlaments - eine Kollektivbiografie. Baden: Verlag für Kultur und Geschichte.

\section{A Canton-Level Data}

This appendix describes the data sources and construction of variables for the 25 Swiss cantons. We drop the canton Jura in our analysis, which was founded only in 1978. Our main outcome variables for the size of government are canton expenditures and revenues. Both are taken from the annual publication 'Statistisches Jahrbuch der Schweiz' for 1890 to 1950 and from 'Öffentliche Finanzen der Schweiz' for 1950 to 2000. All expenditure and revenue categories are expressed per capita and deflated to 2000 Swiss Francs using the annual consumer price index reported in Schuppli and Studer (2004). 
Table 1: Electoral Systems of Swiss Cantons in 1998

\begin{tabular}{llll}
\hline Year PR & Mixed & Seats in \\
Adopted & System & Parliament \\
\hline \hline
\end{tabular}

Adopted prior to 1919:

Ticino (TI)

1891

90

Geneva (GE)

Zug (ZG)

1892

100

Neuchatel (NE)

1894

1895

80

Solothurn (SO)

1896

115

Schwyz (SZ)

1900

1905

144

Basle City (BS)

1911

100

Lucerne (LU)

1912

130

St. Gallen (SG)

1917

170

Zurich (ZH)

\section{7}

180

180

Adopted 1920-1950:

Basle County (BL)

1920

90

Glarus (GL)

1920

80

Thurgau (TG)

1920

130

Aargau (AG)

1921

200

Fribourg (FR)

1921

130

Valais (VS)

1921

130

Berne (BE)

1922

200

Vaud (VD)

1949/1962

180

Adopted 1950-2000:

Schaffhouse (SH)

Nidwalden (NW)

Obwalden (OW)

Uri (UR)

Not Adopted:

Appenzell Outerrhode (AR)

Appenzell Innerrhode (AI)

Grisons (GR)
1952

1982

1986

1992

N/A

$N / A$

$\mathrm{X}$

65

N/A
80

60

55

64

Notes: The table shows the main institutions of each canton's electoral system and its evolution over time. The first column shows the first year the canton parliament was elected under the new proportional rule. Vaud had a mixed electoral system between 1949 and 1962 before adopting a pure proportional system in 1962. Appenzell-Outerrhode allows its districts to adopt proportional representation since 1997 but only one (Herisau) out of six has chosen to do so. Appenzell-Innerrhode and Grisons still have a majoritarian system in place.

Source: Lutz and Strohmann (1998) 
Table 2: Summary Statistics of Canton-Level Data, 1890-2000

\begin{tabular}{|c|c|c|c|c|c|}
\hline & Observations & Mean & Std. Dev & Min & Max \\
\hline \multicolumn{6}{|l|}{ Electoral and Party System } \\
\hline$\overline{\text { Electoral Rule (1= Proportional/Mixed) }}$ & 2775 & 0.62 & 0.49 & 0 & 1 \\
\hline \% Social Democratic Party & 2038 & 17.74 & 10.99 & 0 & 48.46 \\
\hline Number of Parties & 2038 & 4.47 & 1.06 & 2 & 7 \\
\hline Party Fragmentation Index & 2038 & 0.65 & 0.12 & 0.23 & 0.82 \\
\hline Size of Parliament & 2483 & 119.55 & 49.75 & 32 & 257 \\
\hline \multicolumn{6}{|l|}{ Fiscal Policy Variables (log per capita) } \\
\hline Expenditures & 2775 & 7.16 & 1.26 & 4.42 & 9.85 \\
\hline Revenues & 2775 & 7.14 & 1.27 & 4.52 & 9.91 \\
\hline Education & 2775 & 5.25 & 1.57 & 0.82 & 8.44 \\
\hline Welfare & 1775 & 5.60 & 1.03 & 1.07 & 8.16 \\
\hline Roads (per 1,000 inhabitants) & 1900 & 5.59 & 1.11 & 0.05 & 9.30 \\
\hline Agriculture (per 1,000 inhabitants) & 1775 & 4.80 & 1.18 & 0.41 & 7.55 \\
\hline Federal Subsidies (per 1,000 inhabitants) & 2700 & 5.34 & 1.17 & 2.32 & 8.74 \\
\hline \multicolumn{6}{|l|}{ Control Variables } \\
\hline$\overline{\text { Age } 0 \text { to } 19 \text { (in \%) }}$ & 2775 & 33.79 & 6.79 & 15.71 & 45.78 \\
\hline Age 20 to 39 (in \%) & 2775 & 29.98 & 2.55 & 23.14 & 39.21 \\
\hline Age 40 to 64 (in \%) & 2775 & 26.79 & 3.47 & 17.84 & 36.48 \\
\hline Age 65 and older (in \%) & 2775 & 9.44 & 3.56 & 3.75 & 21.03 \\
\hline Population (log) & 2775 & 11.64 & 1.10 & 9.45 & 14.02 \\
\hline Urban Population (in \%) & 2775 & 25.62 & 25.58 & 0 & 100 \\
\hline Employed in Agriculture (in \%) & 2775 & 20.28 & 13.89 & 0.22 & 74.37 \\
\hline Employed in Manufacturing (in \%) & 2775 & 43.56 & 11.34 & 13.80 & 71.46 \\
\hline Car Ownership (in \%) & 2775 & 12.27 & 16.69 & 0 & 59.20 \\
\hline Physicians (per 1,000 population) & 2775 & 0.89 & 0.48 & 0.05 & 3.76 \\
\hline Infant Mortality Rate (per 100,000 births) & 2774 & 52.37 & 48.54 & 0.00 & 286.03 \\
\hline Linguistic Fractionalization Index & 2754 & 0.21 & 0.17 & 0 & 0.76 \\
\hline Religious Fractionalization Index & 2770 & 0.35 & 0.18 & 0 & 0.87 \\
\hline Foreigners (in \%) & 2775 & 11.34 & 7.71 & 1.52 & 40.66 \\
\hline Protestants (in \%) & 2775 & 0.40 & 0.29 & 0.01 & 1.00 \\
\hline Divorced (in \%) & 2775 & 2.05 & 1.92 & 0 & 9.64 \\
\hline Mandatory Budget Referendum & 2775 & 0.62 & 0.49 & 0 & 1 \\
\hline Signature Requirement Initiative & 2775 & 2.43 & 1.82 & 0.003 & 8.5 \\
\hline Law Referendum & 2746 & 0.62 & 0.49 & 0 & 1 \\
\hline President of Executive Directly Elected? & 2775 & 0.24 & 0.43 & 0 & 1 \\
\hline Electoral Cycle (in years) & 2032 & 3.83 & 0.67 & 2 & 6 \\
\hline
\end{tabular}

Notes: The unit of observation is a canton-year pair. Spending and revenues are deflated to 2000 Swiss Francs. Expenditures for agriculture and roads as well as federal subsidies are per 1,000 inhabitants, all other expenditure and revenue categories are per capita. Total expenditures, revenues and education spending are available for 1890-2000, road expenditures since 1925, welfare and agricultural spending since 1930. Urban population reflects the share living in cities above 10,000 people. Linguistic and religious fractionalization are calculated as one minus the Herfindahl index. A larger value indicates a more fragmented population structure. The infant mortality rate is the number of children dying before the age of 1 among 100,000 births. The number of doctors is measured per 1,000 inhabitants. The variables for law referendum and budget referendum are binary indicator equal to one if they are mandatory and zero otherwise. The voter initiative is measured as the signature requirement in percentage of the eligible population. 
Table 3: Proportional Representation and the Scope of Government

\begin{tabular}{|c|c|c|c|c|c|c|c|c|}
\hline & \multicolumn{2}{|c|}{ Education } & \multicolumn{2}{|c|}{ Welfare } & \multicolumn{2}{|c|}{ Roads } & \multicolumn{2}{|c|}{ Agriculture } \\
\hline & $(1)$ & (2) & (3) & (4) & (5) & (6) & $(7)$ & (8) \\
\hline Proportional Representation & $\begin{array}{c}0.174 \\
(0.026)^{\star \star \star}\end{array}$ & $\begin{array}{c}0.101 \\
(0.022)^{\star \star \star}\end{array}$ & $\begin{array}{c}0.201 \\
(0.039)^{\star \star \star}\end{array}$ & $\begin{array}{c}0.331 \\
(0.051)^{\star \star \star}\end{array}$ & $\begin{array}{c}-0.237 \\
(0.045)^{\star \star \star}\end{array}$ & $\begin{array}{c}-0.528 \\
(0.067)^{\star \star \star}\end{array}$ & $\begin{array}{c}-0.392 \\
(0.050)^{\star \star \star}\end{array}$ & $\begin{array}{c}-0.275 \\
(0.058)^{\star \star \star}\end{array}$ \\
\hline Population Size (log) & $\begin{array}{c}0.068 \\
(0.011)^{\star \star \star}\end{array}$ & $\begin{array}{c}-0.111 \\
(0.063)^{*}\end{array}$ & $\begin{array}{c}-0.13 \\
(0.015)^{\star \star \star}\end{array}$ & $\begin{array}{c}0.249 \\
(0.149)^{*}\end{array}$ & $\begin{array}{c}-0.062 \\
(0.021)^{\star \star \star}\end{array}$ & $\begin{array}{c}0.244 \\
(0.153)\end{array}$ & $\begin{array}{c}0.124 \\
(0.022)^{\star \star \star}\end{array}$ & $\begin{array}{c}-1.041 \\
(0.140)^{\star \star \star}\end{array}$ \\
\hline \% Urban Population & $\begin{array}{c}0.005 \\
(0.001)^{\star \star \star}\end{array}$ & $\begin{array}{c}-0.002 \\
(0.001)^{\star}\end{array}$ & $\begin{array}{c}0.002 \\
(0.001)^{\star \star}\end{array}$ & $\begin{array}{c}0.005 \\
(0.002)^{\star \star}\end{array}$ & $\begin{array}{c}-0.013 \\
(0.001)^{\star \star \star}\end{array}$ & $\begin{array}{c}-0.004 \\
(0.002)^{\star \star}\end{array}$ & $\begin{array}{c}-0.011 \\
(0.001)^{\star \star \star}\end{array}$ & $\begin{array}{c}0 \\
(0.001)\end{array}$ \\
\hline Federal Subsidies (log) & $\begin{array}{c}0.052 \\
(0.020)^{\star \star \star}\end{array}$ & $\begin{array}{c}0.134 \\
(0.014)^{\star \star \star}\end{array}$ & $\begin{array}{c}0.124 \\
(0.030)^{\star \star \star}\end{array}$ & $\begin{array}{c}0.101 \\
(0.028)^{\star \star \star}\end{array}$ & $\begin{array}{c}0.328 \\
(0.032)^{\star \star \star}\end{array}$ & $\begin{array}{c}0.134 \\
(0.033)^{\star \star \star}\end{array}$ & $\begin{array}{c}0.407 \\
(0.044)^{\star \star \star}\end{array}$ & $\begin{array}{c}0.36 \\
(0.036)^{\star \star \star}\end{array}$ \\
\hline \% Employed in Agriculture & $\begin{array}{c}-0.004 \\
(0.003)^{\star}\end{array}$ & $\begin{array}{c}-0.007 \\
(0.003)^{\star \star \star}\end{array}$ & $\begin{array}{c}-0.008 \\
(0.004)^{\star}\end{array}$ & $\begin{array}{c}-0.04 \\
(0.005)^{\star \star \star}\end{array}$ & $\begin{array}{c}-0.041 \\
(0.004)^{\star \star \star}\end{array}$ & $\begin{array}{l}-0.002 \\
(0.005)\end{array}$ & $\begin{array}{c}0.041 \\
(0.004)^{\star \star \star}\end{array}$ & $\begin{array}{c}0.028 \\
(0.004)^{\star \star \star}\end{array}$ \\
\hline \% Employed in Industry & $\begin{array}{c}0.007 \\
(0.002)^{\star \star \star}\end{array}$ & $\begin{array}{c}0.005 \\
(0.003)^{\star \star}\end{array}$ & $\begin{array}{c}-0.009 \\
(0.003)^{\star \star \star}\end{array}$ & $\begin{array}{l}-0.004 \\
(0.005)\end{array}$ & $\begin{array}{l}-0.004 \\
(0.003)\end{array}$ & $\begin{array}{c}0.033 \\
(0.006)^{\star \star \star}\end{array}$ & $\begin{array}{c}0.033 \\
(0.004)^{\star \star \star}\end{array}$ & $\begin{array}{c}0.01 \\
(0.005)^{\star \star}\end{array}$ \\
\hline Car Ownership (in \%) & $\begin{array}{c}0.019 \\
(0.003)^{\star \star \star}\end{array}$ & $\begin{array}{c}0.004 \\
(0.003)\end{array}$ & $\begin{array}{c}0.019 \\
(0.004)^{\star \star \star}\end{array}$ & $\begin{array}{c}0.02 \\
(0.005)^{\star \star \star}\end{array}$ & $\begin{array}{c}0.032 \\
(0.006)^{\star \star \star}\end{array}$ & $\begin{array}{c}0.031 \\
(0.006)^{\star \star \star}\end{array}$ & $\begin{array}{c}0.007 \\
(0.007)\end{array}$ & $\begin{array}{c}0.047 \\
(0.006)^{\star \star \star}\end{array}$ \\
\hline Doctors per capita & $\begin{array}{c}0.039 \\
(0.038)\end{array}$ & $\begin{array}{c}-0.073 \\
(0.036)^{\star \star}\end{array}$ & $\begin{array}{c}0.221 \\
(0.060)^{\star \star \star}\end{array}$ & $\begin{array}{c}0.297 \\
(0.069)^{\star \star \star}\end{array}$ & $\begin{array}{c}0.198 \\
(0.060)^{\star \star \star}\end{array}$ & $\begin{array}{c}-0.143 \\
(0.073)^{\star}\end{array}$ & $\begin{array}{c}-0.572 \\
(0.082)^{\star \star \star}\end{array}$ & $\begin{array}{c}-0.36 \\
(0.081)^{\star \star \star}\end{array}$ \\
\hline Infant Mortality Rate (per 100,000 ) & $\begin{array}{c}0.001 \\
(0.000)^{\star \star \star}\end{array}$ & $\begin{array}{c}0.0001 \\
(0.000)^{\star \star \star}\end{array}$ & $\begin{array}{c}0.003 \\
(0.001)^{\star \star \star}\end{array}$ & $\begin{array}{c}0.001 \\
(0.001)^{\star \star \star}\end{array}$ & $\begin{array}{c}0.001 \\
(0.001)\end{array}$ & $\begin{array}{c}0.004 \\
(0.000)^{\star \star \star}\end{array}$ & $\begin{array}{c}0.003 \\
(0.001)^{\star \star \star}\end{array}$ & $\begin{array}{c}0.004 \\
(0.001)^{\star \star \star}\end{array}$ \\
\hline Linguistic Fractionalization & $\begin{array}{c}0.828 \\
(0.065)^{\star \star \star}\end{array}$ & $\begin{array}{c}-0.721 \\
(0.157)^{\star \star \star}\end{array}$ & $\begin{array}{c}-0.177 \\
(0.088)^{\star \star}\end{array}$ & $\begin{array}{c}-0.253 \\
(0.236)\end{array}$ & $\begin{array}{c}0.979 \\
(0.102)^{\star \star \star}\end{array}$ & $\begin{array}{c}-1.258 \\
(0.283)^{\star \star \star}\end{array}$ & $\begin{array}{c}1.123 \\
(0.118)^{\star \star \star}\end{array}$ & $\begin{array}{c}-2.591 \\
(0.269)^{\star \star \star}\end{array}$ \\
\hline Religious Fractionalization & $\begin{array}{c}0.289 \\
(0.081)^{\star \star \star}\end{array}$ & $\begin{array}{c}0.375 \\
(0.135)^{\star \star \star}\end{array}$ & $\begin{array}{c}0.133 \\
(0.105)\end{array}$ & $\begin{array}{l}-0.379 \\
(0.253)\end{array}$ & $\begin{array}{c}-0.729 \\
(0.119)^{\star \star \star}\end{array}$ & $\begin{array}{c}1.3 \\
(0.244)^{\star \star \star}\end{array}$ & $\begin{array}{c}-0.911 \\
(0.134)^{\star \star \star}\end{array}$ & $\begin{array}{c}1.301 \\
(0.247)^{\star \star \star}\end{array}$ \\
\hline Year Fixed Effects & Yes & Yes & Yes & Yes & Yes & Yes & Yes & Yes \\
\hline Canton Fixed Effects & No & Yes & No & Yes & No & Yes & No & Yes \\
\hline Observations & 2690 & 2690 & 1774 & 1774 & 1899 & 1899 & 1774 & 1774 \\
\hline R-squared & 0.94 & 0.97 & 0.86 & 0.92 & 0.83 & 0.9 & 0.82 & 0.93 \\
\hline
\end{tabular}

Notes: The dependent variable is the log of real per capita spending on the categories shown in the first row (all expressed in Swiss Franks at 2000 prices). Expenditures for roads are available since 1925, those for welfare and agriculture since 1930. The variable proportional representation is a binary indicator equal of 1 , if a canton has a proportional or mixed proportional system, and 0 in the case of a majoritarian system. Population is measured in logs, while urban population is calculated as the percentage of people living in cities with more than 10,000 inhabitants. Federal subsidies are the monetary transfers from the federal level measured in logs. Car ownership is the percentage of the population that owns a car while the number of doctors is measured per 1,000 inhabitants. The infant mortality rate is the number of children dying before the age of 1 among 100,000 births. Linguistic and religious fractionalization are measured as Herfindahl indices based on 3 groups respectively. All specifications include year fixed effects and controls for the age structure of the population, even columns also control for canton fixed effects. ${ }^{\star} p<0.1,{ }^{* \star} p<0.05$ and ${ }^{* \star \star} p<0.01$. Robust standard errors are reported in parentheses. 
Table 4: Proportional Representation and the Size of Government

\begin{tabular}{|c|c|c|c|c|}
\hline & \multicolumn{2}{|c|}{ Expenditures } & \multicolumn{2}{|c|}{ Revenues } \\
\hline & $(1)$ & (2) & (3) & $(4)$ \\
\hline Proportional Representation & $\begin{array}{c}0.04 \\
(0.017)^{\star \star}\end{array}$ & $\begin{array}{c}0.01 \\
(0.016)\end{array}$ & $\begin{array}{c}0.028 \\
(0.017)\end{array}$ & $\begin{array}{c}-0.028 \\
(0.016)^{*}\end{array}$ \\
\hline Population Size (log) & $\begin{array}{c}-0.149 \\
(0.008)^{\star \star \star}\end{array}$ & $\begin{array}{l}-0.036 \\
(0.045)\end{array}$ & $\begin{array}{c}-0.143 \\
(0.008)^{\star \star \star}\end{array}$ & $\begin{array}{c}0.014 \\
(0.048)\end{array}$ \\
\hline \% Urban Population & $\begin{array}{c}0.003 \\
(0.000)^{\star \star \star \star}\end{array}$ & $\begin{array}{c}0.002 \\
(0.001)^{\star \star \star}\end{array}$ & $\begin{array}{c}0.003 \\
(0.000)^{\star \star \star}\end{array}$ & $\begin{array}{c}0.002 \\
(0.001)^{\star \star \star}\end{array}$ \\
\hline Federal Subsidies (log) & $\begin{array}{c}0.092 \\
(0.013)^{\star \star \star}\end{array}$ & $\begin{array}{c}0.129 \\
(0.010)^{\star \star \star}\end{array}$ & $\begin{array}{c}0.081 \\
(0.013)^{\star \star \star}\end{array}$ & $\begin{array}{c}0.113 \\
(0.010)^{\star \star \star}\end{array}$ \\
\hline \% Employed in Agriculture & $\begin{array}{c}-0.023 \\
(0.002)^{\star \star \star}\end{array}$ & $\begin{array}{c}-0.006 \\
(0.002)^{\star \star \star}\end{array}$ & $\begin{array}{c}-0.025 \\
(0.002)^{\star \star \star}\end{array}$ & $\begin{array}{c}-0.009 \\
(0.002)^{\star \star \star}\end{array}$ \\
\hline \% Employed in Industry & $\begin{array}{c}-0.015 \\
(0.001)^{\star \star \star}\end{array}$ & $\begin{array}{c}0.002 \\
(0.002)\end{array}$ & $\begin{array}{c}-0.015 \\
(0.001)^{\star \star \star}\end{array}$ & $\begin{array}{c}0.001 \\
(0.002)\end{array}$ \\
\hline Car Ownership (in \%) & $\begin{array}{c}0.026 \\
(0.002)^{\star \star \star}\end{array}$ & $\begin{array}{c}0.015 \\
(0.002)^{\star \star \star}\end{array}$ & $\begin{array}{c}0.025 \\
(0.002)^{\star \star \star}\end{array}$ & $\begin{array}{c}0.015 \\
(0.002)^{\star \star \star}\end{array}$ \\
\hline Doctors per capita & $\begin{array}{c}0.021 \\
(0.030)\end{array}$ & $\begin{array}{c}0.171 \\
(0.028)^{\star \star \star}\end{array}$ & $\begin{array}{c}0.035 \\
(0.032)\end{array}$ & $\begin{array}{c}0.221 \\
(0.031)^{\star \star \star}\end{array}$ \\
\hline Infant Mortality Rate (per 100,000 ) & $\begin{array}{c}0.002 \\
(0.000)^{\star \star \star}\end{array}$ & $\begin{array}{c}0.001 \\
(0.000)^{\star \star \star}\end{array}$ & $\begin{array}{c}0.002 \\
(0.000)^{\star \star \star}\end{array}$ & $\begin{array}{c}0.001 \\
(0.000)^{\star \star \star}\end{array}$ \\
\hline Linguistic Fractionalization & $\begin{array}{c}0.389 \\
(0.041)^{\star \star \star}\end{array}$ & $\begin{array}{c}-0.419 \\
(0.099)^{\star \star \star}\end{array}$ & $\begin{array}{c}0.3 \\
(0.049)^{\star \star \star}\end{array}$ & $\begin{array}{c}-0.743 \\
(0.111)^{\star \star \star}\end{array}$ \\
\hline Religious Fractionalization & $\begin{array}{c}0.218 \\
(0.049)^{\star \star \star}\end{array}$ & $\begin{array}{c}-0.257 \\
(0.085)^{\star \star \star}\end{array}$ & $\begin{array}{c}0.15 \\
(0.053)^{\star \star \star}\end{array}$ & $\begin{array}{c}-0.263 \\
(0.087)^{\star \star \star}\end{array}$ \\
\hline Year Fixed Effects & Yes & Yes & Yes & Yes \\
\hline Canton Fixed Effects & No & Yes & No & Yes \\
\hline Observations & 2690 & 2690 & 2690 & 2690 \\
\hline R-squared & 0.96 & 0.98 & 0.95 & 0.98 \\
\hline
\end{tabular}

Notes: The dependent variable is the log per capita expenditures in columns (1) and (2) and log per capita revenues in columns (3) and (4) both measured in Swiss Franks at 2000 prices. The variable 'proportional representation' equals one if a canton has a proportional or mixed proportional electoral system in place and zero otherwise. Population size is calculated as the log of a canton's population, while the urban population measures the percentage people living in cities with more than 10,000 inhabitants. All specifications also include year fixed effects and controls for the age structure of the population, even columns also control for canton fixed effects. * $p<0.1$ ** $p<0.05$ and ${ }^{\star \star *} p<0.01$. Robust standard errors in parentheses. See also notes to previous table. 
Table 5: Proportional System and Changes in the Legislature

\begin{tabular}{|c|c|c|c|c|c|c|c|c|}
\hline & \multicolumn{2}{|c|}{ Number of Legislators } & \multicolumn{2}{|c|}{ Number of Parties } & \multicolumn{2}{|c|}{ Party Fragmentation } & \multicolumn{2}{|c|}{ Left-Wing Party } \\
\hline & $(1)$ & $(2)$ & (3) & (4) & (5) & (6) & (5) & (6) \\
\hline Proportional Representation & $\begin{array}{c}-12.655 \\
(1.327)^{\star \star \star}\end{array}$ & $\begin{array}{c}2.444 \\
(0.803)^{\star \star \star}\end{array}$ & $\begin{array}{c}0.05 \\
(0.049)\end{array}$ & $\begin{array}{c}0.587 \\
(0.066)^{\star \star \star}\end{array}$ & $\begin{array}{c}0.081 \\
(0.007)^{\star \star \star}\end{array}$ & $\begin{array}{c}0.137 \\
(0.010)^{\star \star \star}\end{array}$ & $\begin{array}{c}0.066 \\
(0.005)^{\star \star \star}\end{array}$ & $\begin{array}{c}0.056 \\
(0.007)^{\star \star \star}\end{array}$ \\
\hline Population Size (log) & $\begin{array}{c}50.428 \\
(0.615)^{\star \star \star}\end{array}$ & $\begin{array}{c}-4.792 \\
(2.287)^{\star \star}\end{array}$ & $\begin{array}{c}0.637 \\
(0.143)^{\star \star \star}\end{array}$ & $\begin{array}{c}-0.611 \\
(0.230)^{\star \star \star}\end{array}$ & $\begin{array}{c}0.013 \\
(0.002)^{\star \star \star}\end{array}$ & $\begin{array}{c}0.007 \\
(0.011)\end{array}$ & $\begin{array}{c}0.018 \\
(0.002)^{\star \star \star}\end{array}$ & $\begin{array}{c}-0.046 \\
(0.013)^{\star \star \star}\end{array}$ \\
\hline Linguistic Fractionalization Index & $\begin{array}{c}-61.011 \\
(3.358)^{\star \star \star}\end{array}$ & $\begin{array}{c}-26.005 \\
(5.554)^{\star \star \star}\end{array}$ & $\begin{array}{c}-0.522 \\
(0.115)^{\star \star \star}\end{array}$ & $\begin{array}{c}-1.17 \\
(0.334)^{\star \star \star}\end{array}$ & $\begin{array}{c}-0.061 \\
(0.014)^{\star \star \star}\end{array}$ & $\begin{array}{c}-0.117 \\
(0.030)^{\star \star \star}\end{array}$ & $\begin{array}{c}-0.149 \\
(0.012)^{\star \star \star}\end{array}$ & $\begin{array}{c}-0.21 \\
(0.027)^{\star \star \star}\end{array}$ \\
\hline Religious Fractionalization Index & $\begin{array}{c}13.74 \\
(3.619)^{\star \star \star}\end{array}$ & $\begin{array}{c}-46.61 \\
(5.040)^{\star \star \star}\end{array}$ & $\begin{array}{c}2.375 \\
(0.137)^{\star \star \star}\end{array}$ & $\begin{array}{l}-0.673 \\
(0.420)\end{array}$ & $\begin{array}{c}0.403 \\
(0.013)^{\star \star \star}\end{array}$ & $\begin{array}{l}-0.026 \\
(0.039)\end{array}$ & $\begin{array}{c}0.231 \\
(0.012)^{\star \star \star}\end{array}$ & $\begin{array}{l}-0.007 \\
(0.027)\end{array}$ \\
\hline Year Fixed Effects & Yes & Yes & Yes & Yes & Yes & Yes & Yes & Yes \\
\hline Canton Fixed Effects & No & Yes & No & Yes & No & Yes & No & Yes \\
\hline Observations & 2391 & 2391 & 1963 & 1963 & 1963 & 1963 & 1963 & 1963 \\
\hline R Squared & 0.79 & 0.96 & 0.46 & 0.75 & 0.65 & 0.83 & 0.53 & 0.83 \\
\hline
\end{tabular}

Notes: The table reports regression estimates where the dependent variable is the size of the canton parliament (columns (1) and (2), the number of parties in the legislature (columns (3) and (4)), one minus the Herfindahl index of party fragmentation in canton parliaments (columns (5) and (6)) and the percentage of seats held by the socialist or social democratic party in canton parliaments (columns (7) and (8)). The main independent variable is an indicator equal to one if the canton has adopted proportional representation and zero otherwise. All specifications include year fixed effects, even columns also control for canton fixed effects. Robust standard errors are reported in parentheses. ${ }^{*} p<0.10,{ }^{* \star} p<0.05$ and ${ }^{* \star *} p<0.01$ 
Table 6: Direct and Indirect Effects of Proportional Representation

\begin{tabular}{|c|c|c|c|c|c|c|}
\hline & \multicolumn{3}{|c|}{ Expenditures } & \multicolumn{3}{|c|}{ Revenues } \\
\hline & $(1)$ & $(2)$ & (3) & (4) & $(5)$ & (6) \\
\hline Proportional Representation & $\begin{array}{l}-0.012 \\
(0.021)\end{array}$ & $\begin{array}{c}-0.074 \\
(0.022)^{\star \star \star}\end{array}$ & $\begin{array}{c}0.235 \\
(0.084)^{\star \star}\end{array}$ & $\begin{array}{c}-0.018 \\
(0.021)\end{array}$ & $\begin{array}{c}-0.085 \\
(0.020)^{\star \star \star}\end{array}$ & $\begin{array}{c}0.148 \\
(0.083)^{\star}\end{array}$ \\
\hline Party Fragmentation & & $\begin{array}{c}0.291 \\
(0.088)^{\star \star \star}\end{array}$ & $\begin{array}{c}0.610 \\
(0.129)^{\star \star \star}\end{array}$ & & $\begin{array}{c}0.342 \\
(0.086)^{\star \star \star}\end{array}$ & $\begin{array}{c}0.581 \\
(0.120)^{\star \star \star}\end{array}$ \\
\hline PR * Party Fragmentation & & & $\begin{array}{c}-0.572 \\
(0.142)^{\star \star \star}\end{array}$ & & & $\begin{array}{c}-0.431 \\
(0.137)^{\star \star \star}\end{array}$ \\
\hline Number of Parties & & $\begin{array}{c}0.002 \\
(0.009)\end{array}$ & $\begin{array}{c}0.007 \\
(0.009)\end{array}$ & & $\begin{array}{c}0.005 \\
(0.009)\end{array}$ & $\begin{array}{l}-0.009 \\
(0.009)\end{array}$ \\
\hline Number of Legislators & & $\begin{array}{c}0.001 \\
(0.001)\end{array}$ & $\begin{array}{c}0.001 \\
(0.001)\end{array}$ & & $\begin{array}{c}0.001 \\
(0.0005)^{\star}\end{array}$ & $\begin{array}{c}0.001 \\
(0.0005)^{\star}\end{array}$ \\
\hline \% Left-Wing Parties & & $\begin{array}{c}0.511 \\
(0.091)^{\star \star *}\end{array}$ & $\begin{array}{c}0.518 \\
(0.090)^{\star \star \star}\end{array}$ & & $\begin{array}{c}0.434 \\
(0.089)^{\star \star \star}\end{array}$ & $\begin{array}{c}0.439 \\
(0.088)^{\star \star \star}\end{array}$ \\
\hline Canton Controls & Yes & Yes & Yes & Yes & Yes & Yes \\
\hline Year Fixed Effects & Yes & Yes & Yes & Yes & Yes & Yes \\
\hline Canton Fixed Effects & Yes & Yes & Yes & Yes & Yes & Yes \\
\hline Observations & 1954 & 1954 & 1953 & 1954 & 1954 & 1954 \\
\hline R Squared & 0.98 & 0.98 & 0.98 & 0.98 & 0.98 & 0.98 \\
\hline
\end{tabular}

Notes: The table reports regression results where the dependent variable is log per capita total expenditures (columns (1)-(3)) and log per capita revenues (columns (4)-

(6)). All specifications include year and canton fixed effects and the same control variables than table 4 . Columns (1) and (4) reestimate the baseline for the subset of observations for which we have information on party seats in canton parliaments. Column (2) and (5) add the size of the legislature, number of parties, party fragmentation (as measured by 1 minus the Herfindahl index) and the percentage of seats held by the socialist or social democratic party. Columns (3) and (6) allow party fragmentation to have different effects in proportional and plurality systems. Robust standard errors are reported in parentheses. ${ }^{*} p<0.10,{ }^{* *} p<0.05$ and ${ }^{* \star *} p<0.01$. 
Table 7: Summary Statistics Local Data

\begin{tabular}{lccc}
\hline & Observations & Mean & Std. Dev. \\
\hline \hline & & & \\
Political System & & & \\
\hline Executive Elected by Plurality Rule & 5081 & 0.72 & 0.45 \\
Mandated Electoral Rule for Executive & 5081 & 0.53 & 0.50 \\
Size of Executive (log) & 5056 & 1.77 & 0.29 \\
Community has Parliament & 5852 & 0.19 & 0.40 \\
Legislative Elected by Proportional Rule & 778 & 0.77 & 0.42 \\
Mandated Electoral Rule for Legislative & 1134 & 0.14 & 0.35 \\
Size of Local Parliament (log) & 670 & 3.42 & 0.49 \\
& & & \\
Size of Government & & & \\
Administrative Personnel & 5852 & 0.86 & 5.65 \\
Administrative Personnel (log) & 5852 & -1.03 & 1.00 \\
Budget Deficit? & 3761 & 0.31 & 0.46 \\
& & & \\
Control Variables & & & \\
Population & 5852 & 2491 & 7771 \\
Nonemployed (\%) & 5852 & 35.91 & 13.89 \\
Children under 15 (\%) & 5852 & 20.58 & 9.11 \\
Population 65 and Above (\%) & 5852 & 31.16 & 32.43 \\
Employed in Primary Sector (\%) & 5852 & 7.42 & 10.22 \\
Employed in Secondary Sector (\%) & 5852 & 36.51 & 37.00 \\
Protestants (\%) & 5852 & 42.47 & 29.73 \\
Canton Language French or Italian & 5852 & 0.45 & 0.50 \\
Community Located in the Alps & 5805 & 0.31 & 0.46 \\
& & &
\end{tabular}

Notes: The table shows means, standard deviations and extreme values for our sample of local communities in 1988, 1994, 1998 and 2005. The size of the executive and parliament (if any) is expressed in logs. Administrative personnel represents the size of the administration per 100 inhabitants (both in levels and logs). Information on whether the community ran a budget deficit is not available in 1988. The percentage of nonemployed and employed in primary sector are measued in terms of the labor force while the percentage of children and protestants in terms of the total population. 
Table 8: Canton Mandates and the Size of Local Government

\begin{tabular}{|c|c|c|c|c|}
\hline & \multirow{2}{*}{\multicolumn{2}{|c|}{$\begin{array}{l}\text { Communities that Adopted Electoral } \\
\text { Rule }\end{array}$}} & \multicolumn{2}{|c|}{ Communities with Mandates } \\
\hline & & & & Border only \\
\hline & $\begin{array}{c}\text { Legislative } \\
(1) \\
\end{array}$ & $\begin{array}{c}\text { Executive } \\
(2) \\
\end{array}$ & $\begin{array}{c}\text { Executive } \\
\text { (3) } \\
\end{array}$ & $\begin{array}{c}\text { Executive } \\
\text { (4) } \\
\end{array}$ \\
\hline Proportional Rule & $\begin{array}{c}0.017 \\
(0.096)\end{array}$ & $\begin{array}{l}-0.038 \\
(0.042)\end{array}$ & $\begin{array}{c}0.058 \\
(0.072)\end{array}$ & $\begin{array}{c}0.155 \\
(0.335)\end{array}$ \\
\hline Log Population & $\begin{array}{c}-0.177 \\
(0.060)^{\star \star \star}\end{array}$ & $\begin{array}{c}-0.485 \\
(0.024)^{\star \star \star}\end{array}$ & $\begin{array}{c}-0.756 \\
(0.062)^{\star \star \star}\end{array}$ & $\begin{array}{l}-0.658 * * \star \\
(0.137)\end{array}$ \\
\hline Canton Language French or Italian & $\begin{array}{l}-0.255 \\
(0.105)^{\star \star}\end{array}$ & $\begin{array}{c}-0.06 \\
(0.052)\end{array}$ & $\begin{array}{l}-0.120 \\
(0.035)^{\star \star \star}\end{array}$ & $\begin{array}{l}-0.164 \\
(0.355)\end{array}$ \\
\hline$\%$ Protestants & $\begin{array}{c}0.004 \\
(0.002)^{\star}\end{array}$ & $\begin{array}{c}0.001 \\
(0.001)\end{array}$ & $\begin{array}{c}0.003 \\
(0.001)^{\star \star \star}\end{array}$ & $\begin{array}{l}-0.005 \\
(0.008)\end{array}$ \\
\hline \% Children under 15 & $\begin{array}{c}-0.077 \\
(0.017)^{\star \star \star}\end{array}$ & $\begin{array}{l}-0.017 \\
(0.004)^{\star \star \star}\end{array}$ & $\begin{array}{c}-0.020 \\
(0.005)^{\star \star *}\end{array}$ & $\begin{array}{c}-0.04 \\
(0.037)\end{array}$ \\
\hline$\%$ Nonemployed & $\begin{array}{c}-0.043 \\
(0.012)^{\star \star \star}\end{array}$ & $\begin{array}{c}-0.009 \\
(0.003)^{\star \star \star}\end{array}$ & $\begin{array}{c}-0.007 \\
(0.004)^{\star}\end{array}$ & $\begin{array}{l}-0.01 \\
(0.029)\end{array}$ \\
\hline \% Employed in Primary Sector & $\begin{array}{c}0 \\
(0.007)\end{array}$ & $\begin{array}{c}0.006 \\
(0.003)^{\star \star}\end{array}$ & $\begin{array}{l}-0.001 \\
(0.002)\end{array}$ & $\begin{array}{l}-0.034^{*} \\
(0.018)\end{array}$ \\
\hline Community Located in the Alps & $\begin{array}{c}0.193 \\
(0.107)^{\star}\end{array}$ & $\begin{array}{l}-0.025 \\
(0.040)\end{array}$ & $\begin{array}{l}-0.030 \\
(0.051)\end{array}$ & $\begin{array}{l}-0.316 \\
(0.340)\end{array}$ \\
\hline Population Size Dummies & Yes & Yes & Yes & Yes \\
\hline Year Fixed Effects & Yes & Yes & Yes & Yes \\
\hline Observations & 620 & 2381 & 2679 & 67 \\
\hline R Squared & 0.17 & 0.37 & 0.31 & 0.37 \\
\hline
\end{tabular}

Notes: The table reports regression results where the dependent variable is the log of administrative personnel per capita. The main independent variable is whether a community has proportional rule in place. The baseline in the first two columns is shown for communities that choose their electoral system for the legislative (column 1) or executive (column 2). In column (3), we run the same specification on the sample of communities where the canton mandates the electoral rule for the executive. In column (4), we further restrict the analysis to communities with mandated proportional rule close to the border with communities where the canton mandates plurality rule. All specifications include year effects. See the previous table for a description of the control variables. Standard errors are clustered at the canton level. ${ }^{*} P<0.1,{ }^{\star \star} p<0.05$ and ${ }^{\star \star *} p<0.01$. 
Table 9: Propensity Score Matching

\begin{tabular}{|c|c|c|}
\hline & Communities th & Electoral Rule \\
\hline & $\begin{array}{l}\text { Legislative } \\
\text { (1) }\end{array}$ & $\begin{array}{l}\text { Executive } \\
\text { (2) }\end{array}$ \\
\hline Log Population & $\begin{array}{c}0.979 \\
(0.162) \star \star \star\end{array}$ & $\begin{array}{c}1.189 \\
(0.069)^{\star \star \star}\end{array}$ \\
\hline Canton Language French or Italian & $\begin{array}{c}1.721 \\
(0.367)^{\star \star \star}\end{array}$ & $\begin{array}{c}7.568 \\
(0.656)^{\star \star \star}\end{array}$ \\
\hline$\%$ Protestants & $\begin{array}{c}-0.015 \\
(0.007)^{\star}\end{array}$ & $\begin{array}{l}-0.006 \\
(0.004)\end{array}$ \\
\hline \% Children under 15 & $\begin{array}{l}-0.068 \\
(0.046)\end{array}$ & $\begin{array}{l}-0.011 \\
(0.013)\end{array}$ \\
\hline$\%$ Nonemployed & $\begin{array}{c}0.085 \\
(0.027)^{\star \star \star}\end{array}$ & $\begin{array}{c}0.027 \\
(0.012)^{\star \star}\end{array}$ \\
\hline \% Employed in Primary Sector & $\begin{array}{c}-0.054 \\
(0.027)^{\star \star}\end{array}$ & $\begin{array}{c}-0.017 \\
(0.009)^{*}\end{array}$ \\
\hline Community Located in the Alps & $\begin{array}{c}0.651 \\
(0.370)^{\star \star}\end{array}$ & $\begin{array}{c}-1.529 \\
(0.229)^{\star \star \star}\end{array}$ \\
\hline Year Fixed Effects & Yes & Yes \\
\hline Canton Fixed Effects & No & Yes \\
\hline Observations & 621 & 2,679 \\
\hline R Squared & 0.21 & 0.43 \\
\hline Log-likelihood & -270.88 & -917.92 \\
\hline Treatment on the Treated (ATT) & & \\
\hline Nearest Neighbor Matching & $\begin{array}{c}0.106 \\
(0.127)\end{array}$ & $\begin{array}{c}-0.05 \\
(0.100)\end{array}$ \\
\hline Biweight Kernel Matching & $\begin{array}{c}0.124 \\
(0.162)\end{array}$ & $\begin{array}{l}-0.049 \\
(0.098)\end{array}$ \\
\hline Communities with Common Support & & \\
\hline _Treated & 436 & 1,008 \\
\hline _Untreated & 177 & 1,340 \\
\hline $\begin{array}{l}\text { Notes: The table reports the coefficients fro } \\
\text { binary indicator equal to one if the comm } \\
\text { (column (2)) according to proportional rule a } \\
\text { canton fixed effects. The matching procec } \\
\text { matching (using a biweight kernel). We imp } \\
\text { trim } 2 \text { percent of the observations with the } h \\
\text { The average treatment on the treated effec } \\
\text { together with the number of observations in } \\
\text { not adjusted for the first stage estimation } \\
p<0.01 \text {. }\end{array}$ & $\begin{array}{l}\text { a logit regression w } \\
\text { ity elects the parlia } \\
\text { d zero otherwise. Al } \\
\text { ire implements both } \\
\text {;e common support } \\
\text { hest/lowest values o } \\
\text { for both matching } n \\
\text { he treated and untre } \\
\text { if the propensity sc }\end{array}$ & $\begin{array}{l}\text { endent variable is a } \\
\text { nn (1)) or executive } \\
\text { ns include year and } \\
\text { eighbors and kernel } \\
\text { nsity score and also } \\
\text { ed propensity score. } \\
\text { borted at the bottom } \\
\text { Standard errors are } \\
\text { ** } p<0.05 \text { and }{ }^{* \star \star}\end{array}$ \\
\hline
\end{tabular}


Figure 1: Adoption of Proportional Representation, 1890-2000

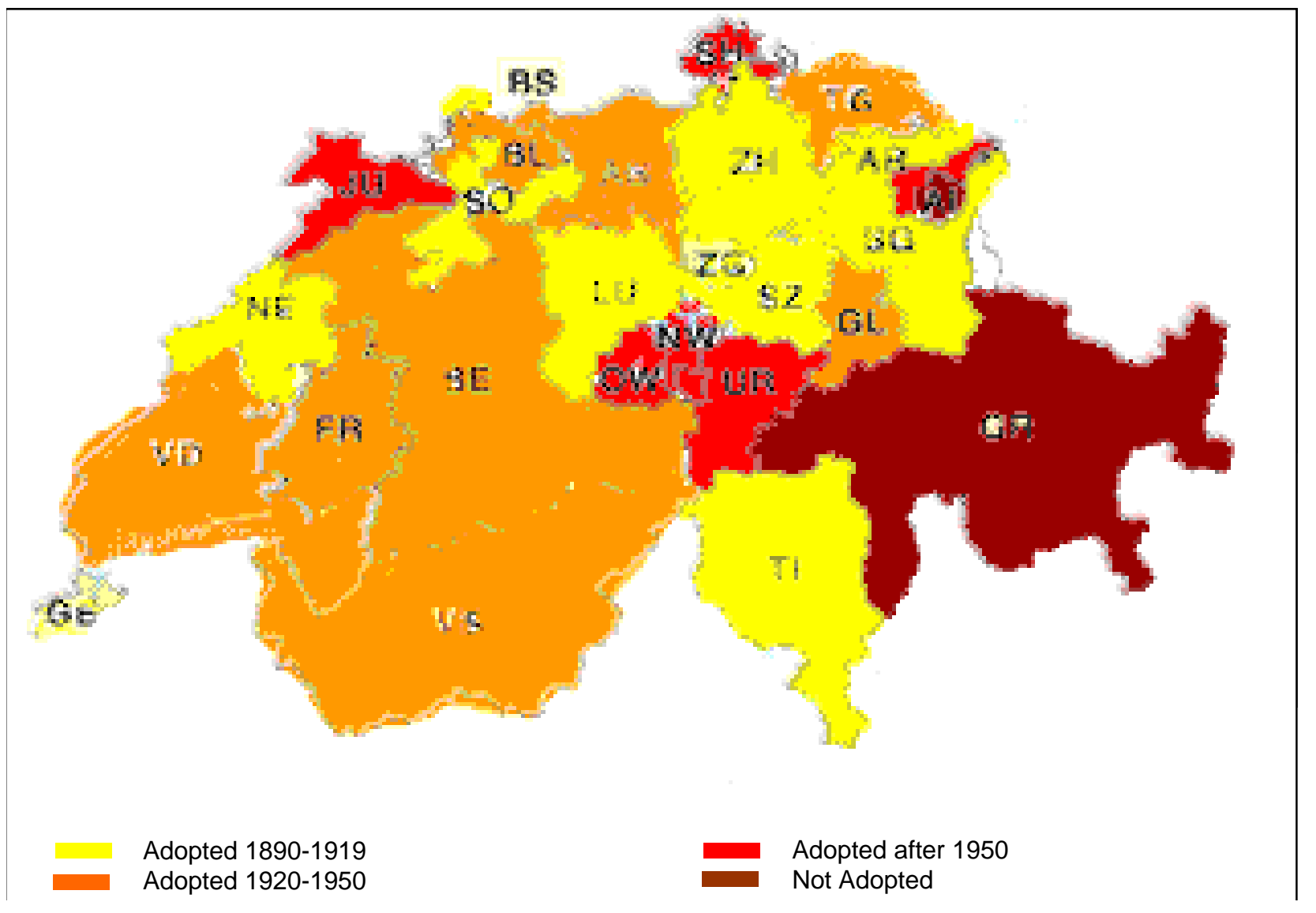




\section{CESifo Working Paper Series}

for full list see www.cesifo-group.org/wp

(address: Poschingerstr. 5, 81679 Munich, Germany, office@cesifo.de)

2897 Michael McBride and Stergios Skaperdas, Conflict, Settlement, and the Shadow of the Future, December 2009

2898 Ben J. Heijdra and Laurie S. M. Reijnders, Economic Growth and Longevity Risk with Adverse Selection, December 2009

2899 Johannes Becker, Taxation of Foreign Profits with Heterogeneous Multinational Firms, December 2009

2900 Douglas Gale and Piero Gottardi, Illiquidity and Under-Valuation of Firms, December 2009

2901 Donatella Gatti, Christophe Rault and Anne-Gaël Vaubourg, Unemployment and Finance: How do Financial and Labour Market Factors Interact?, December 2009

2902 Arno Riedl, Behavioral and Experimental Economics Can Inform Public Policy: Some Thoughts, December 2009

2903 Wilhelm K. Kohler and Marcel Smolka, Global Sourcing Decisions and Firm Productivity: Evidence from Spain, December 2009

2904 Marcel Gérard and Fernando M. M. Ruiz, Corporate Taxation and the Impact of Governance, Political and Economic Factors, December 2009

2905 Mikael Priks, The Effect of Surveillance Cameras on Crime: Evidence from the Stockholm Subway, December 2009

2906 Xavier Vives, Asset Auctions, Information, and Liquidity, January 2010

2907 Edwin van der Werf, Unilateral Climate Policy, Asymmetric Backstop Adoption, and Carbon Leakage in a Two-Region Hotelling Model, January 2010

2908 Margarita Katsimi and Vassilis Sarantides, Do Elections Affect the Composition of Fiscal Policy?, January 2010

2909 Rolf Golombek, Mads Greaker and Michael Hoel, Climate Policy without Commitment, January 2010

2910 Sascha O. Becker and Ludger Woessmann, The Effect of Protestantism on Education before the Industrialization: Evidence from 1816 Prussia, January 2010

2911 Michael Berlemann, Marco Oestmann and Marcel Thum, Demographic Change and Bank Profitability. Empirical Evidence from German Savings Banks, January 2010 
2912 Øystein Foros, Hans Jarle Kind and Greg Shaffer, Mergers and Partial Ownership, January 2010

2913 Sean Holly, M. Hashem Pesaran and Takashi Yamagata, Spatial and Temporal Diffusion of House Prices in the UK, January 2010

2914 Christian Keuschnigg and Evelyn Ribi, Profit Taxation and Finance Constraints, January 2010

2915 Hendrik Vrijburg and Ruud A. de Mooij, Enhanced Cooperation in an Asymmetric Model of Tax Competition, January 2010

2916 Volker Meier and Martin Werding, Ageing and the Welfare State: Securing Sustainability, January 2010

2917 Thushyanthan Baskaran and Zohal Hessami, Globalization, Redistribution, and the Composition of Public Education Expenditures, January 2010

2918 Angel de la Fuente, Testing, not Modelling, the Impact of Cohesion Support: A Theoretical Framework and some Preliminary Results for the Spanish Regions, January 2010

2919 Bruno S. Frey and Paolo Pamini, World Heritage: Where Are We? An Empirical Analysis, January 2010

2920 Susanne Ek and Bertil Holmlund, Family Job Search, Wage Bargaining, and Optimal Unemployment Insurance, January 2010

2921 Mariagiovanna Baccara, Allan Collard-Wexler, Leonardo Felli and Leeat Yariv, Gender and Racial Biases: Evidence from Child Adoption, January 2010

2922 Kurt R. Brekke, Roberto Cellini, Luigi Siciliani and Odd Rune Straume, Competition and Quality in Regulated Markets with Sluggish Demand, January 2010

2923 Stefan Bauernschuster, Oliver Falck and Niels Große, Can Competition Spoil Reciprocity? - A Laboratory Experiment, January 2010

2924 Jerome L. Stein, A Critique of the Literature on the US Financial Debt Crisis, January 2010

2925 Erkki Koskela and Jan König, Profit Sharing, Wage Formation and Flexible Outsourcing under Labor Market Imperfection, January 2010

2926 Gabriella Legrenzi and Costas Milas, Spend-and-Tax Adjustments and the Sustainability of the Government’s Intertemporal Budget Constraint, January 2010

2927 Piero Gottardi, Jean Marc Tallon and Paolo Ghirardato, Flexible Contracts, January 2010 
2928 Gebhard Kirchgässner and Jürgen Wolters, The Role of Monetary Aggregates in the Policy Analysis of the Swiss National Bank, January 2010

2929 J. Trent Alexander, Michael Davern and Betsey Stevenson, Inaccurate Age and Sex Data in the Census PUMS Files: Evidence and Implications, January 2010

2930 Stefan Krasa and Mattias K. Polborn, Competition between Specialized Candidates, January 2010

2931 Yin-Wong Cheung and Xingwang Qian, Capital Flight: China’s Experience, January 2010

2932 Thomas Hemmelgarn and Gaetan Nicodeme, The 2008 Financial Crisis and Taxation Policy, January 2010

2933 Marco Faravelli, Oliver Kirchkamp and Helmut Rainer, Social Welfare versus Inequality Concerns in an Incomplete Contract Experiment, January 2010

2934 Mohamed El Hedi Arouri and Christophe Rault, Oil Prices and Stock Markets: What Drives what in the Gulf Corporation Council Countries?, January 2010

2935 Wolfgang Lechthaler, Christian Merkl and Dennis J. Snower, Monetary Persistence and the Labor Market: A New Perspective, January 2010

2936 Klaus Abberger and Wolfgang Nierhaus, Markov-Switching and the Ifo Business Climate: The Ifo Business Cycle Traffic Lights, January 2010

2937 Mark Armstrong and Steffen Huck, Behavioral Economics as Applied to Firms: A Primer, February 2010

2938 Guglielmo Maria Caporale and Alessandro Girardi, Price Formation on the EuroMTS Platform, February 2010

2939 Hans Gersbach, Democratic Provision of Divisible Public Goods, February 2010

2940 Adam Isen and Betsey Stevenson, Women’s Education and Family Behavior: Trends in Marriage, Divorce and Fertility, February 2010

2941 Peter Debaere, Holger Görg and Horst Raff, Greasing the Wheels of International Commerce: How Services Facilitate Firms’ International Sourcing, February 2010

2942 Emanuele Forlani, Competition in the Service Sector and the Performances of Manufacturing Firms: Does Liberalization Matter?, February 2010

2943 James M. Malcomson, Do Managers with Limited Liability Take More Risky Decisions? An Information Acquisition Model, February 2010

2944 Florian Englmaier and Steve Leider, Gift Exchange in the Lab - It is not (only) how much you give ..., February 2010 
2945 Andrea Bassanini and Giorgio Brunello, Barriers to Entry, Deregulation and Workplace Training: A Theoretical Model with Evidence from Europe, February 2010

2946 Jan-Emmanuel De Neve, James H. Fowler and Bruno S. Frey, Genes, Economics, and Happiness, February 2010

2947 Camille Cornand and Frank Heinemann, Measuring Agents' Reaction to Private and Public Information in Games with Strategic Complementarities, February 2010

2948 Roel Beetsma and Massimo Giuliodori, Discretionary Fiscal Policy: Review and Estimates for the EU, February 2010

2949 Agnieszka Markiewicz, Monetary Policy, Model Uncertainty and Exchange Rate Volatility, February 2010

2950 Hans Dewachter and Leonardo Iania, An Extended Macro-Finance Model with Financial Factors, February 2010

2951 Helmuth Cremer, Philippe De Donder and Pierre Pestieau, Education and Social Mobility, February 2010

2952 Zuzana Brixiová and Balázs Égert, Modeling Institutions, Start-Ups and Productivity during Transition, February 2010

2953 Roland Strausz, The Political Economy of Regulatory Risk, February 2010

2954 Sanjay Jain, Sumon Majumdar and Sharun W. Mukand, Workers without Borders? Culture, Migration and the Political Limits to Globalization, February 2010

2955 Andreas Irmen, Steady-State Growth and the Elasticity of Substitution, February 2010

2956 Bengt-Arne Wickström, The Optimal Babel - An Economic Framework for the Analysis of Dynamic Language Rights, February 2010

2957 Stefan Bauernschuster and Helmut Rainer, From Politics to the Family: How Sex-Role Attitudes Keep on Diverging in Reunified Germany, February 2010

2958 Patricia Funk and Christina Gathmann, How do Electoral Systems Affect Fiscal Policy? Evidence from State and Local Governments, 1890 to 2005, February 2010 